\title{
Martial Law in the Anglo-Boer War, I899-1902
}

Although it had been widely used since the I880s, detention without trial in the continent of Africa did not generate the kind of debates in the metropolis about the rule of law and the constitution which had been engendered by the use of martial law after the Morant Bay revolt. ${ }^{\mathrm{I}}$ This was to change at the end of the nineteenth century, when the outbreak of war in South Africa in 1899 led to the proclamation of martial law both in the Cape Colony and in Natal, which would be followed (among other things) by widescale detention without trial. ${ }^{2}$ In contrast to Jamaica, where it was used against an insurgent black population, in the Cape martial law was used to control white British subjects, thousands of whom had joined in rebellion when the Boers invaded the borderlands. In this colony with responsible government and a liberal legal tradition, the legal and political elites were generally loath to regard martial law simply as the rule of the military commander, but sought to subject it to the rule of law in ways which

I See R. W. Kostal, A Jurisprudence of Power: Victorian Empire and the Rule of Law (Oxford, Oxford University Press, 2005); and Priyamvada Gopal, Insurgent Empire: Anticolonial Resistance and British Dissent (London, Verso, 20I9), ch. 2.

${ }^{2}$ For histories of the war, see Thomas Pakenham, The Boer War (London, Weidenfeld \& Nicolson, 1979); Denis Judd and Keith Surridge, The Boer War: A History (London, John Murray, 2002); and Bill Nasson, The War for South Africa (Cape Town, Tafelberg, 20I0). In the following discussion, we will not consider the experience of Africans during the war and under martial law: however, for an important study, see Bill Nasson, Abraham Esau's War: A Black South African War in the Cape, I899-I902 (Cambridge, Cambridge University Press, I99I). 
had been recommended by Eyre's critics on the Jamaica committee. ${ }^{3}$ This in turn raised questions for officials in London, about how to reconcile a commitment to the rule of law with the wartime demands of the imperial military, in the context of a war which divided public opinion. ${ }^{4}$ Furthermore, cases from this war would require the Judicial Committee of the Privy Council to be more explicit than any imperial court had hitherto been on the exact nature of martial law.

In the aftermath of the Jamaica rebellion, a Diceyan view of martial law - which subjected all actions taken under it to the scrutiny of the common law - became widely accepted. At the same time, many questions about its nature remained unsettled. One question was whether civilian courts could hold the military to account during the crisis, or whether they could exercise their jurisdiction only after it had passed. ${ }^{5}$ Another question concerned the nature of the indemnity which would be granted to those who had violated legal rights under martial law. Did an indemnity act simply substitute 'the despotism of Parliament for the prerogative of the Crown ${ }^{6}$ - thereby satisfying a formalistic vision of the rule of law - or was parliament to apply the kind of tests of necessity and good faith which common law courts were expected to apply when judging particular acts, acting as a kind of court for the nation ensuring fidelity to a broader culture of the rule of law?

These questions were widely debated during the Anglo-Boer war. As the example of the Cape in this era shows, the degree to which a 'substantive' view of the rule of law could shape political and legal policy depended on how committed particular actors were to its

3 See Martin Chanock, The Making of South African Legal Culture I902-I936: Fear, Favour and Prejudice (Cambridge, Cambridge University Press, 200I); and Albie Sachs, Justice in South Africa (Berkeley, University of California Press, 1973).

${ }^{4}$ See G. R. Searle, A New England? Peace and War I886-I9I8 (Oxford, Clarendon Press, 2004), pp. 284-29I; Kenneth O. Morgan, 'The Boer War and the Media (I899-I902)', Twentieth Century British History, vol. I3:I (2002), pp. I-I6.

5 Even Dicey accepted that governments could not keep the peace in times of crisis 'without occasional use of arbitrary authority': A. V. Dicey, Introduction to the Study of the Law of the Constitution, 5 th ed. (London, MacMillan, I879), p. 34I.

${ }^{6}$ Dicey, The Law of the Constitution, p. 342.

7 See David Dyzenhaus, 'Schmitt v. Dicey: Are States of Emergency inside or outside the Legal Order?', Cardozo Law Review, vol. 27 (2006), pp. 2005-2039; and David Dyzenhaus, 'The Puzzle of Martial Law', University of Toronto Law Journal, vol. 59 (2009), pp. I-64. 
culture, and how influential their voices could be. In a colony with a strong liberal political and legal tradition, and where the targets of martial law were white British subjects forming part of the political community, a broad, substantive vision of the rule of law was championed both by ministers and by members of the judiciary. They had many opportunities to explore the relationship between martial law and civilian law, given that the civilian courts remained open. At the same time, imperial military commanders and their civilian masters at the metropolis wanted their ability to defeat the enemy to remain unfettered, and often argued for a much broader vision of martial law than was espoused by the liberal politicians at the Cape. Questions about the nature of martial law would also receive the attention of metropolitan judges sitting in the Judicial Committee of the Privy Council, who had their own understanding of the legal basis of imperial rule. In this context, the language of a 'substantive' rule of law constantly interrupted imperial military efforts to assume plenary powers, though how far it would prevail remained a matter of negotiation. As shall be seen, martial law was not treated as a legal void, a state of siege in which the military's command held full sway, but rather as a space whose boundaries were defined by a process of careful negotiation between imperial, local and military authorities. Equally, when it came to legislating for indemnity, the matter was not treated simply as a formal legislative fiat, but as the product of a process in which judgments were to be made about the conduct being indemnified.

In what follows, attention will be focused on the use of martial law in the British colonies of the Cape of Good Hope and Natal. Martial law was also imposed by the British in the former republics, which were formally annexed to the crown in I 900 , just as the first phase of the war was coming to an end and peace seemed likely. ${ }^{8}$ However, the former republics continued to be treated as territories under military occupation outside the imperial constitutional system. Despite General Roberts's early proclamation that anyone found in arms would be

${ }^{8}$ Martial law was proclaimed in the new Orange River Colony on 3 I May I900, and in Transvaal on September I, after the capture of their respective capitals, Bloemfontein on ${ }_{3} 3$ March and Pretoria on 5 June. 
'dealt with as rebels', ${ }^{9}$ combatants in the former republics continued to be regarded as enemy 'Boers' and treated as prisoners of war when captured. The advice of the Law Officers was that as long as the war continued, and 'the resistance of those who were formerly subjects of the South African Republic and Orange Free State' had not in fact been suppressed, enemy belligerents could not be treated as rebels. ${ }^{\text {IO }}$ The British military response to the enemy Boer commandoes was to adopt a scorched earth policy, which entailed the resettlement of large populations in concentration camps which they were not permitted to leave without permission. ${ }^{\text {I }}{ }^{\text {O Over }} 26,000$ Boer women and children and over I 8,000 Africans were to die from malnutrition and disease in these camps. Although this policy was widely debated, not least because of the publicity generated by humanitarian critics such as Emily Hobhouse, ${ }^{\mathrm{I} 2}$ there was little discussion of the legalities of martial law in these areas, which remained under military administration until the end of the war, with no local civilian authority to question their powers.

\section{The First Invasion, October I 899-October 1900}

Launching a pre-emptive strike in response to British threats to their independence, the two Boer republics declared war on I I October I 899, and sent commandoes into Natal and the Cape Colony. In the border areas which were invaded, up to Io, ००० of the Dutch-speaking population supported the invasion. ${ }^{\mathrm{I} 3}$ Within four days, martial law was proclaimed in a number of border districts in Natal and the Cape, and by the middle of November, all of Natal and all the Cape districts bordering the Orange Free State and the South African

9 Proclamation, 7 June I900 (relating to the Orange River Colony), PP I900 (Cd. 26I) LVI. 389 , enc. in No 80, p. I9I.

Io Opinion of 3 I July I90I, CO $885 / 15$, No. $95 \mathrm{~A}$.

${ }^{\text {II }}$ In June I90I, 85,4 IO Boers - the large majority women and children - remained in concentration camps (mainly in Transvaal and the Orange River Colony): PP I90 I (Cd. 608) X. 549. See further Aidan Forth, Britain's Empire of Camps (Berkeley, University of California Press, 2017), ch. 5 .

${ }^{12}$ Figures taken from Alexander B. Downes, Targeting Civilians in War (Ithaca, Cornell University Press, 2008), p. I6r. For Hobhouse, see Robert Eales, The Compassionate Englishwoman: Emily Hobhouse in the Boer War (Cape Town, UCT Press, 201 5 ).

${ }^{13}$ G. H. L. Le May, British Supremacy in South Africa I 899-I907 (Oxford, Clarendon Press, I965), p. 43. 
Republic were under martial law. After the initial invasion, the Boer troops did not seek to penetrate deeper into the Cape Colony, but besieged the towns of Kimberley, Ladysmith and Mafeking. The tide of the campaign turned with the arrival of an overwhelming amount of imperial military manpower, and by the middle of May each of the besieged towns had been relieved, Bloemfontein had been captured and Pretoria was soon to fall. With the Boers in retreat, and their republics annexed, it appeared to many that the war was largely over. Martial law was gradually withdrawn from a number of areas in the Cape between July and October, but plans for winding down martial law in all areas were arrested when a second invasion of the Cape began in December. In this phase of the war, the authorities were faced with the problem of how to deal with a large number of captured rebels, at a time when there was an expectation that the war would soon end.

It soon became apparent that the debates which had followed Governor Eyre's proclamation of martial law in I 865 had not fully clarified the legal position regarding martial law. Although the dominant view among common lawyers was that 'martial law' was nothing more than the crown's common law right to suppress insurrection, and that its justification came from necessity and not from any proclamation, ${ }^{\mathrm{I}}{ }^{4}$ the Colonial Office had made it clear through Lord Carnarvon's I 867 Circular Despatch that Governors were expected to make proclamations of martial law in times of crisis and to set out procedures on how to implement it. Discussing the matter in January I900, the High Commissioner for South Africa, Sir Alfred Milner, observed that 'the exact nature of the powers conferred by such a proclamation of Martial Law' is 'extremely difficult to decide.' ${ }^{15}$ Considering martial law to be 'the temporary suspension of law - a purely arbitrary and singularly ill-defined condition', he regretted that the law had not made better provision for emergencies,

${ }^{14}$ Dicey, The Law of the Constitution, pp. 267-276; J. F. Stephen, A History of the Criminal Law of England, 3 vols. (London, MacMillan and Co., I883), vol. I, pp.207-216; and Robert M. King, 'Martial Law I', Cape Law Journal, vol. I7 (I900), pp. 30-42. See also Kostal, A Jurisprudence of Power, pp. 45 5-459.

I5 CO $879 / 64 / 5$, No. I26, p. I6I at p. I62. Compare the report of the Cape's Attorney General (Richard Solomon) on 25 November I 899, in PP I900 (Cd. 420) LVI. 595, enc. 2 in No. I, p. 2. 
as had been done in Europe through legal definitions of the state of siege, ${ }^{16}$ and thought that 'the arbitrary power of the military should be exercised in accordance with some clearly defined principles. ${ }^{17} \mathrm{On}$ the vexed question of whether martial law entirely suspended the civilian courts, or whether 'the ordinary law still exercises an unimpaired ascendancy', Milner felt that a hybrid system could be used, under which ordinary crime could be left to ordinary courts, while treason would be dealt with by martial law courts, which themselves could include 'a civilian element, in the person of a magistrate or judge'. ${ }^{\mathrm{I}}{ }^{8}$

Milner was not the only one who regretted that the law had not been placed on firmer foundations. Sir John Ardagh, Director of Military Intelligence at the War Office, also thought that a 'State of Siege' should be 'legalised and regularised under the most careful safeguards and restrictions', both to protect Governors and Officers from later legal action, and to show soldiers that they had no 'legal license to hang, shoot, flog and destroy as they please'. ${ }^{19}$ Ardagh's understanding of the current law was that a proclamation of martial law was 'exercised by the prerogative of the king' and suspended the ordinary law. It permitted 'summary methods of arrest, trial and punishment to be carried out, usually by military forces', since it reversed the normal presumption that the ordinary process of law was sufficient to maintain peace. In his view, however, martial law did not entirely oust the jurisdiction of the ordinary courts: though they would not exercise it 'flagrante bello', they could subsequently hold crown officers responsible for the use of unjustifiable force. ${ }^{20}$

Others in the military had a more extensive view of the prerogative powers of the crown, which was closer to that articulated by W. F. Finlason during the Jamaica debates. For instance, the Deputy Judge Advocate-General J. Scott argued in May I90 I that sentences imposed by martial law courts would not expire at the end of the war,

${ }^{16}$ Cecil Headlam (ed.), The Milner Papers, vol. 2 (London, Cassell, I933), pp. 59-60.

${ }^{17}$ Milner to Roberts, I2 January I900, CO $48 / 545 / 3845$, f. 258.

${ }_{18}$ Milner to Chamberlain, 3 January I900, CO $879 / 64 / 5$, No. I26, p. I6I at pp. I63-I64.

$19 \mathrm{PRO}_{30 / 40 / 19}$. At the same time, he was also concerned at political interference with the exercise of emergency powers.

${ }^{20}$ Memorandum and notes by Ardagh, December I900 and I 8 July I90I, PRO $30 /$ 40/I9. 
since (he argued) the crown had a prerogative power to resort to martial law. ${ }^{2 \mathrm{I}}$ His view seemed to be supported by no less a figure than the Lord Chancellor, Halsbury, who privately told Chamberlain that penal servitude sentences passed by a martial law court would be legally valid after the war ended. ${ }^{22}$ This opinion raised eyebrows, not least because it was inconsistent with the view he had expressed as a Law Officer in I $878,{ }^{23}$ as well as being inconsistent with the rules set out in I 867. This question was referred to the Law Officers, Finlay and Carson, who reiterated the common law orthodoxy that martial law was only 'the temporary application of force by the Executive under a condition of affairs which renders necessary the abrogation of civil rights as established by law' and that, when it ended, prisoners would be entitled to their freedom, and the civil courts would have jurisdiction over them. ${ }^{24}$

In this context of contested understandings, the parameters and operation of martial law became the object of negotiations between various civil and military parties. Rather than seeing martial law as a state of exception where all law was silent and the executive stepped in to defend the salus populi, or as a state where the rules of common law necessity simply applied, they saw it as a legal order whose parameters had to be defined. Matters were complicated by the fact that the war was an imperial one, but the rebellion a colonial one. Although the military who would exercise the martial law powers were under the command of officers - Lords Roberts and Kitchener - who were responsible to the War Office in London, martial law was proclaimed at the Cape by the Governor under the seal of the colony. As the Governor of a colony with responsible government, he was expected to act on the advice of ministers who were answerable to a colonial parliament. At the same time, as an appointee of the imperial government dealing with an imperial matter, he also had to take heed

${ }^{21} \mathrm{He}$ also argued that their proceedings had 'been conducted with such regularity that relief under a writ of habeas corpus, if it were applied for, would not be granted'. Opinion dated 23 May I90I, CO 885/I 5 , No. 84A.

${ }_{22}$ Note by Chamberlain 28 April I900, CO 4I $7 / 305 / 4219$, f. I80.

${ }^{23}$ Law Officers' Opinion, 23 July I 878 , CO $879 /{ }_{13} / 5$, p. 30 I.

${ }^{24}$ Opinion dated 6 July I90I, CO $885 /$ I $_{5}$, No. 88. See also the Law Officers' debate with Judge Advocate-General Sir Francis Jeune over the status of martial law courts: CO 879/68/3, p. I27, enc. in No. I22; Law Officers' Opinion, I June I900, CO 885/ I 5 , No. 38 . 
of the demands of the Colonial Office. Furthermore, the military and civilian parties had often divergent interests. The military wanted to have as free a hand as possible, to enable them to conduct the war as efficiently as possible. By contrast, the Cape ministry, which at the outbreak of the war was led by W. P. Schreiner and depended on the support of the Afrikaner Bond, had no desire for a regime which would unduly antagonise the majority Dutch-speaking white community. Sitting between these two, the Colonial Office favoured a policy which would not hamper the war effort, but which would be defensible not only at the Cape, but also before British public opinion.

\section{Military and Civilian Trials}

The kind of arrangement which Milner envisaged began to be put in place at the start of the war. An Army Order issued On 7 December I 899 set out the offences to be dealt with under martial law (including treason, sedition and aiding and abetting the enemy) and the procedure to be used. ${ }^{25}$ The military agreed that ordinary offences should be left as far as possible to be dealt with in civilian courts, and that trials for martial law offences should 'follow the rules of military law'. ${ }^{26}$ While Milner was happy with this arrangement, the Cape ministry insisted that high treason cases at least should be presided over by a Justice of the Supreme Court. ${ }^{27}$ The Colonial Office was content to concede the point, considering that the presence of a judge would increase public confidence in the tribunal, and oblige the ministry both to assume responsibility for punishing the rebels and to pass an indemnity act. ${ }^{28}$ The military reluctantly agreed, and on 3 February, Kitchener issued a Circular Memorandum stating that (save in cases of urgency), high treason cases would be heard by a mixed commission of four officers and a presiding judge. ${ }^{29}$

The Cape ministry nominated Justice W. H. Solomon to sit in these cases. ${ }^{30}$ Having accepted the position, Solomon told Chief Justice Sir

25 PP I902 (Cd. 98I) LVII. 327, pp. 2 I-22.

26 CO 879/64/5, No. I32, p. I68; PP I902 (Cd. 98I), pp. 23-24.

$27 \mathrm{CO} 879 / 64 / 5$, enc. I in No. 383 , p. 373 .

${ }_{28}$ CO 879/63/2, No. I3 I, p. 207; Notes by Lambert and Cox, 28 February I900, CO $48 / 545 / 6203$, f. 435 .

29 PP I902 (Cd. 98I), pp. 26-27. For the War Office's continuing doubts, CO 879/63/2, No. I30, p. 206.

30 CO $879 / 64 / 5$, enc. in No. 436, p. 434 . 
Henry de Villiers that he did not 'quite like the work' he had undertaken, given the anomalous status of the court and the need for indemnity legislation to legalise anything it did. However, he felt 'it is most desirable in the interests of justice that a judge should preside at the trial': if martial law courts were bodies unknown to the ordinary law, Solomon was at least keen to make them follow civilian precedents as far as possible. ${ }^{3 \mathrm{I}}$ In the event, by the time that the War Office had agreed to Solomon's appointment at the end of March, Milner had come to the view that the question needed reconsideration. ${ }^{32}$ In his view, the procedure set out by the military circulars was 'an odd mixture of military and civil jurisdiction, without the prompt effectiveness of the former or the unquestionable legality of the latter'. With the war by now looking as if it might soon be over, the proposal was overtaken by events, as political attention turned to creating structures to deal with the large number of rebels to be tried after the anticipated end of hostilities. ${ }^{33}$

Rather than being tried in mixed tribunals, rebels were tried during the first phase of the war in both civilian and military tribunals. The first to be tried - in a civil court - were thirty-six rebel prisoners captured after the engagement at Sunnyside (near Kimberley). Since it was the policy of the Boer republics to give nationality to those British subjects who joined them, Presidents Kruger and Steyn of the Boer republics sent a telegram after their capture to the Foreign Secretary requesting that they be treated as prisoners of war. ${ }^{34}$ Faced with the threat of reprisals if this were not done - and the alternative risk of having the men acquitted by a sympathetic jury - officials considered postponing any trial until the war was over, and in the meantime removing them (along with the Boer prisoners of war) to St Helena, beyond the reach of any habeas corpus application. However, they were advised by the Law Officers that a choice had to be made between holding them as prisoners of war or putting them on trial as traitors. ${ }^{35}$ The decision was taken to try them, since Milner thought that treating

${ }^{31}$ W. H. Solomon to H. de Villiers, I6 February I900, de Villiers Papers, National Library of South Africa (Cape Town), MSC 7 (Box 8).

${ }_{32}$ CO 879/63/2, No. I33, p. 208; CO 879/63/1, No. 546, p. I76; CO 879/63/2, No. I38, p. 2 IO.

33 Headlam (ed.), The Milner Papers, vol. 2, p. I06. ${ }^{34}$ PP I900 (Cd. 26I), p. 5.

35 Opinion dated 6 February I900, CO $885 /$ I 5 , No. I9A. 
them as prisoners of war would only encourage more to rebel. ${ }^{36}$ The Presidents of the republics were accordingly informed that those owing allegiance to the crown would be tried, and that they would be held personally responsible for any treatment of British prisoners inconsistent with the usages of war. ${ }^{37}$ The Sunnyside rebels were tried for treason before Buchanan J towards the end of April, and were convicted after they refused to plead, perhaps realising that since they were captured in battle, they had no real defence. The heaviest sentences - of five years' penal servitude - were imposed on three ringleaders, while twenty-two others were given three-year prison sentences. ${ }^{38}$ In all, forty men were convicted of treason in cases tried before the Supreme Court during the course of I900, with twenty-three more convicted for treason in trials held before circuit judges. $^{39}$

Eighteen trials for treason or assisting the enemy were also conducted by the military, before the decision was taken in the middle of April to conduct no more martial law trials for treason. ${ }^{40}$ The fact that such trials were being held when the civil courts were open was questioned in parliament by Sir Henry CampbellBannerman, ${ }^{4 \mathrm{I}}$ who drew particular attention to the cases of J. Booysens and N. A. van der Walt, who were tried by the military at Naauwpoort on I2 March. ${ }^{42}$ The fact that such trials had taken place did not trouble officials at the Colonial Office. Sensing that this was a political attempt by the Liberal leader to drive a wedge between the civil and military authorities which should be 'nipped in the bud', assistant undersecretary of state Fred Graham minuted that

Martial law having been proclaimed, with the assent of the Civil Govt of the Colony, the civil power ceases to have any responsibility. The military can if

${ }^{36} \mathrm{CO} 879 / 64 / 5$, p. 2 IO. Lambert also pointed out the risk that those mistakenly arrested might challenge their detention: note of 8 February I900, $\mathrm{CO} 417 / 305 / 4219$, f. I67.

37 PP I900 (Cd. 26I), p. 6.

${ }_{38}$ W[estern] C[ape] A[rchives] AG 2067; and The Times, 24 April I900, p. 5.

39 The figures are taken from the printed lists in WCA AG 2 II 7.

${ }^{4 \circ}$ Figures taken from PP I902 (Cd. 98I), pp. 2I 3 ff. There were also cases of breaches of regulations and arms offences. On the decision not to try more cases, see CO 879/63/ 2, No. 175 , p. 268.

${ }^{41}$ Parl. Debs., 4th ser., vol. 85, cols. 776 (6 July I900), 948 (9 July I900).

$4^{2}$ They were tried by the military after the Cape premier, W. P. Schreiner, had questioned their detention without trial: see CO 879/64/5, No. 200, p. 242. 
they choose hang every inhabitant without trial, they only run the risk of not being indemnified \& therefore of being criminally prosecuted later on. A fortiori they can administer the criminal law of the colony.

Chamberlain's telling private reaction was, 'I know nothing of \& am not responsible for the administration of martial law.' His diplomatic reply to Campbell-Bannerman confirmed the men's sentences, but added that 'military tribunals are not now taking cognisance of offences against the criminal law of the colony.'43

\section{The Creation of the Special Treason Court}

The number of British subjects who had joined the rebels in the frontier areas when the Boers invaded - whether as combatants or collaborators - ran into the thousands. As the rebellion faded, it became evident that it was neither possible nor desirable to try them all, either in civil or in military courts. ${ }^{44}$ By February I900, there was general agreement that all but the ringleaders should be allowed to return to their farms on surrendering their arms, though they would remain liable to be called to account for their actions later. ${ }^{45}$ Meanwhile, the military was instructed to keep those regarded as ringleaders under arrest and to hold full preliminary investigations into their cases. Most of the rebels south of the Orange River took advantage of this offer: by May, over 5,000 Cape rebels had surrendered. ${ }^{46}$

This did not resolve the problem of what to do with the rebels. As Chamberlain realised, there were difficulties both in the use of martial law courts (whose sentences would expire) and in the use of civilian ones (whose juries might be partial and unreliable). Although he considered - as a last resort - the possibility of prolonging martial law until the longest sentence had expired, his preferred option (which

$43 \mathrm{CO}_{4}$ 8/549/2 I3 I 5, f. 455 ; see Parl. Debs., 4th ser., vol. 85, col. 948 (9 July I900).

${ }_{44}$ CO $879 / 63 / 2$, No. I27, p. I 80 at p. I 8 I.

45 PP I902 (Cd. 98I), p. 28; PP I900 (Cd. 264), enc. I in No. I3 at p. 39; CO 879/64/5, No. 373, p. 362 ; No. 397, p. 396; No. 5I 2, p. 555 . Milner had originally wanted the rebels to enter into recognisances; but the Law Officers pointed out that such legal forms could not be used under martial law: Opinion dated 26 February I900, CO $885 /$ I 5 , No. 23.

${ }^{46}$ H. A. Shearing, 'The Cape Rebel of the South African War, I899-I902', University of Stellenbosch Ph.D. thesis, 2004, pp. 9I-92. 
he proposed to Milner on Io March) was to create a special statutory commission to try rebel cases. ${ }^{47}$ While the Cape ministry also favoured a statutory court to deal with charges of high treason, ${ }^{48}$ there was less agreement between the Colonial Office and the ministry over what to do with rank and file rebels. The ministry argued that they should be given an amnesty, as had been done after the more violent Canadian rebellions of I837-I $838 .{ }^{49}$ Chamberlain rejected the analogy, and argued that such an amnesty would be equivalent to 'offering a premium to rebellion'. ${ }^{50} \mathrm{He}$ wanted to see the 'political disarmament of persons who have shown that they would use the vote as they have used the rifle to destroy the Empire'. ${ }^{5 \text { I }}$ A way out of the impasse was proposed by Attorney General Richard Solomon in a minute drafted on 17 May. Under his plan, rebels should be divided into two classes: those in the first class - the ringleaders - would be tried for high treason before a statutory commission with the powers of the Supreme Court. Those in the second class would be investigated by a quasi-judicial commission, and be liable to disfranchisement for a five-year period. ${ }^{52}$

Milner realised that passing the legislation necessary for this tribunal would not be straightforward, since politicians at the Cape did not themselves agree over how to deal with rank and file rebels. Although the Progressive party strongly supported Solomon's policy of disfranchisement, Bond members wanted a complete amnesty. The division of opinion both in the Cape cabinet and in parliament generated an impasse, which created its own problems. As Milner realised, if elections had to be called to break the deadlock, the shape

$47 \mathrm{CO} 879 / 63 / 2$, No. I03, p. I 54; Milner agreed that a statutory commission was the best way to proceed, and passed the proposals to the ministry: CO 879/63/2, No. I49, p. 252, PP I900 (Cd. 264), p. II.

${ }^{48}$ PP I900 (Cd. 264), enc. 2 in No. 6, p. I3; CO 879/66/2, No. I73, p. 256.

49 PP 1902 (Cd. 264), No. 7, p. I4.

$5 \circ$ CO 879/63/2, No. I82, p. 273; PP I900 (Cd. 264), No. 4, p. 7; PP I900 (Cd. 420), No. 5, p. Iо; cf. PP I900 (Cd. 264), No. Io, p. 33; and CO 48/546/I3530, f. 309.

${ }^{51} \mathrm{CO} 48 / 546 / 20938$, f. 747. Chamberlain noted that 'The object of H.M.G. is prevention \& not punishment', but H. W. Just reminded him that the Dutch colonists could no more be deprived of their vote for political reasons than Australians or Canadians could be. Le May, British Supremacy in South Africa, p. 69.

${ }^{52}$ PP 1900 (Cd. 264), enc. I in No. I3, pp. 37-38; and T. R. H. Davenport, The Afrikaner Bond: The History of a South African Political Party (Cape Town, Oxford University Press, I966), p. 2 I 8. 
of the next parliament might well be determined by rebel votes. ${ }^{53} \mathrm{He}$ considered imperial legislation to be the only way out of the dilemma, but Chamberlain was averse to this idea, both because colonists would resent the constitutional interference and because they would 'throw all the blame upon us if its proceedings did not satisfy them'. Chamberlain also worried about the difficulty of passing such a measure at Westminster, in the face of obstruction from those who opposed the war. ${ }^{54}$

At the same time that he sent his suggestion for a special commission to Milner, Chamberlain also sent it to the Governor of Natal, Sir Walter Hely-Hutchinson. ${ }^{55}$ Unlike ministers at the Cape, those in Natal wanted no clemency to be shown to the relatively small number of Dutch-speaking rebels who had attacked the property of their 'English friends and neighbours'. Rather than allowing the rank and file to return home, they intended to prosecute them in the ordinary courts. ${ }^{56}$ HelyHutchinson consequently told Chamberlain that his ministers considered their civil courts to be adequate, and thought that the appointment of a judicial commission would be seen as a slight on their impartiality. ${ }^{57}$ Chamberlain, however, had other political reasons for wanting Natal to agree to his proposals: as he well understood, it would be much more difficult to pass the legislation needed for a special commission at the Cape if Natal did not also agree to it. Once this delicate matter had been explained to Natal's ministers in late April, they agreed to appoint a special commission, if the Cape undertook to do the same. ${ }^{58}$

Given the concern that a special court made up only of the colony's own judges might be seen as a mere device to get rid of juries, Natal's Justice A. Weir Mason suggested creating a single commission for both colonies, to be staffed by six judges taken equally from the Cape, Natal and England. ${ }^{59}$ Although this proposal was approved by the Colonial

53 CO 879/63/2, No. I75, p. 268.

$54 \mathrm{CO} 879 / 63 / 2$, No. I 54, p. 256 ; No. I 82, p. 273 at p. 274.

$55 \mathrm{CO} 879 / 63 / 2$, No. I04, p. I 56; No. I 55, p. 257.

${ }^{56} \mathrm{CO} 879 / 63 / 2$, enc. 8 in No. I27, p. I85.

57 CO 879/63/2, No. I 58 , p. 258.

${ }^{8}$ CO I79/2II/II603, f. 45I; CO 879/63/2, No. I65, p. 264; CO 879/63/I, No. 643, p. 207.

59 Memorandum by Justice A. Weir Mason, 20 April I900, CO I 79/2 I I/I 5653. 
Office, ${ }^{60}$ there were practical problems in the way of making the necessary arrangements with the Cape government. With a large number of treason cases ready for trial, Natal wanted the legislation passed by the end of May. ${ }^{6 \mathrm{r}}$ However, the Cape was far from ready to pass its bill, given that ministers there were 'hopelessly divided'. Milner therefore pressed Natal to go ahead, to help 'make things march here'. ${ }^{62}$ Under these circumstances, Chamberlain abandoned the idea of a joint commission, ${ }^{63}$ and Natal ended by passing a bill it had not wanted in order to nudge the reluctant Cape legislature into passing its bill. By the time Natal's Act passed at the end of June, treason trials had already commenced in its Supreme Court, since Attorney General Bale did not feel it was fair to continue to keep prisoners in gaol waiting for the legislation to pass. ${ }^{64}$ Under the Act, all cases of treason committed before or after its passing were to be tried by a Special Court, composed of three commissioners, all of whom had to be qualified for judicial office, and at least one of whom had to be a Judge of the Supreme Court. ${ }^{65}$ After this Act passed, the principal clerk at the Colonial Office, H. W. Just, anticipated that between 400 and 500 treason trials would follow: ${ }^{66}$ 'the difference will be that in Natal all or almost all rebels will be brought up for trial, whilst at the Cape it will only be a proportion of the whole number. ${ }^{97}$ Given the shortage of judicial personnel in Natal, the ministry asked for an English judge to be appointed. None could be spared, but eventually the Chief Justice of British Guiana, Sir William Smith, was selected. ${ }^{68}$

Meanwhile, in the Cape, Milner suspected ministers of 'trying to bluff me into letting off nine tenths of the rebels by threatening not to pass the act of indemnity for acts committed under martial law'. He had no intention of backing down, even if this entailed a ministerial

${ }^{60} \mathrm{CO} 879 / 63 / \mathrm{I}$, No. 756, p. 249; cf. Minute of 30 April I900 by Fred Graham, CO 48/ $546 / 13239$

${ }^{61} \mathrm{CO} 879 / 63 / 2$, No. 226, p. $307 . \quad{ }^{62}$ CO 879/63/I, No. 768, p. 254.

${ }^{63} \mathrm{CO} 879 / 63 / 2$, No. 229 , p. 308 . See further CO 48/546/16799.

${ }^{64}$ Hely-Hutchinson's Diary of events, 9 June I900, CO I79/2I2/20946, f. 539; R. v. Gert, Arnold and Hendrik Boers (I900) 2 I NLR I I6.

${ }_{5}$ The Act is in PP 1902 (Cd. 98I), p. 50. The power to dissolve the court was vested in the Governor, who also had the power to appoint a second Special Court.

${ }^{66} \mathrm{CO}$ I 79/2I 2/20945, f. $568 .{ }^{67}$ Minute of 28 May I900, CO I79/2 I I/I 5649, f. 653.

${ }^{68} \mathrm{CO}$ I79/2I3/2I333, f. I9; CO I79/2I3/24I99, f. 2 I 5. 
crisis and a dissolution. ${ }^{69}$ With Prime Minister Schreiner unable to persuade his caucus to accept the policy of disfranchisement, his ministry was replaced in the middle of June, with Sir J. Gordon Sprigg as Prime Minister and Sir James Rose-Innes as Attorney General. $^{70}$ The new ministry had enough support to pass an Indemnity and Special Tribunals Act through the Assembly. The measure was opposed in the legislative council by Sir Henry de Villiers, who argued that rebels should be tried in ordinary courts. He was answered by Rose-Innes, who insisted that the rebels would get a fairer trial before this tribunal than they would before a jury in the ordinary courts. ${ }^{7 \mathrm{I}}$ The bill finally obtained Milner's assent as Governor on I I October.

It empowered the Governor to appoint a Special Court of three, to try all cases of high treason and 'all cases of crimes of a political character' committed before or within six months after the passing of the Act. A 'political' act was defined to be any act which in the Attorney General's opinion was 'incidental to, and forming part of, political disturbances'. The court would be made up of at least two Cape Supreme Court judges and a barrister of ten years' standing. It was to have the powers of the Supreme Court, but cases were to be heard without a jury, and indictments could be brought on the basis of preliminary investigations undertaken by the military. Only those considered to be ringleaders were to be prosecuted before the Special Court, and criteria were included for determining whether a person was a ringleader. The rank and file were to be brought before commissioners appointed by the Attorney General, with those found guilty of treason or crimes of a political character being disfranchised for five years. Those who had surrendered in response to certain proclamations, and whose names had been entered on a list by a resident magistrate, were to be presumed to have committed the offence charged, unless the contrary was proved. ${ }^{72}$ The act also provided for a system of appeals: there was an appeal from the commissioners to the Special Court, and, where the Special Court

\footnotetext{
69 Milner to Chamberlain, 28 May I900, CO 48/546/I6799, f. 60I.

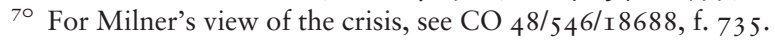

${ }^{71}$ Cape Times, 27 September I900.

${ }^{2}$ Act No. 6 of I900. For the act, see PP I902 (Cd. 98I), p. 58 . For Milner's comments

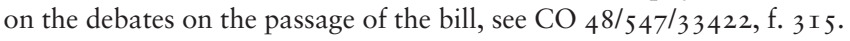


was not unanimous, there could be an appeal to the Supreme Court. In order to head off a proposal in the Assembly for a select committee to inquire into the administration of martial law, powers were also given to any commissioners the Governor might appoint for such an inquiry. ${ }^{73}$

Both Natal and the Cape also legislated for indemnity. Natal's Act indemnified the Governor and officer commanding the military and those acting under them for bona fide acts done under martial law. It also confirmed martial law sentences, deeming them to be sentences passed by legally constituted courts. The immunity conferred was for acts done 'before, during or after the existence of Martial Law'. ${ }^{74}$ Such a broad and prospective immunity was out of line with precedent legislation, and contrasted with the provision in the Cape Act, where the indemnity ran only to I 2 October $1900 .{ }^{75}$ The Cape legislation also indemnified the Governor and the officer commanding the Queen's forces and those acting under them for anything done in good faith as necessary for the suppression of hostilities; but, unlike the Natal Act, it included a presumption of good faith. It also confirmed the sentences imposed by military courts, and deemed all arrests for treason to have been lawful. Furthermore, it confirmed that prisoners could be kept in legal places of confinement in the colony, or elsewhere, as the Governor directed. While the validation of martial law sentences by legislation was hardly consistent with the rule of law, it had been done previously both in the Cape and in Natal. On this occasion, it was not a matter of controversy, since only a handful of rebels had been tried for treason by martial law courts, and fewer still remained in custody. Of those convicted for treason by martial law courts in the Cape, only three had unexpired sentences by the time the act came into force in October. ${ }^{76}$ Since their sentences were shorter than those of the

73 PP I900 (Cd. 420), No. I4; enc. I in No. 20, pp. 78, 88-9I.

74 Act No. I 5 of I900. For a copy of the act, see PP I900 (Cd. 420), Appendix II, p. I I 8.

75 Comparing them, permanent undersecretary Sir Montagu Ommanney noted, 'It is a pity that the Natal precedent was not followed; another Indemnity Act debate at the Cape is not a pleasant prospect.' Note 25 November I900, CO $48 / 548 / 34209$, f. 8.

76 Albertus Bloem (sentenced to five years' penal servitude I January I900, commuted to two years' imprisonment with hard labour), Nicolas van der Walt (sentenced to ten years' penal servitude 9 March I900, commuted to one year) and Andrew Loxton (sentenced to two years' imprisonment with hard labour, 7 April I900). PP I902 (Cd. 
Sunnyside rebels who had been tried by civil courts, they were hardly likely to demand a retrial.

\section{Legal Challenges in the Supreme Court}

In February I900, with the British press already taking a keen interest in South African events, H. C. M. Lambert - first class clerk in the South African department at the Colonial Office - noted that '[i]t will be a difficult campaign to meet because martial law is essentially illegal.' In his view, 'the essential thing' was to 'avoid collision with the Supreme Court'. ${ }^{77}$ It did not take long for detainees at the Cape to seek writs de homine libero exhibendo. A number of cases were brought to the court early in the war by rebels who had been arrested in martial law areas on suspicion of aiding the enemy, before being moved to Cape Town with other (Boer) prisoners of war, and then (when writs were issued) returned to the places where they had been arrested..$^{78}$ In these cases, the Cape Supreme Court was willing to issue writs to military officers in martial law areas - thereby asserting its jurisdiction - though without determining whether the detainees would ultimately be released..$^{79}$ No final decision was made in these initial cases, for the military released the men in question. ${ }^{80}$

Caution was required for, as Lambert noted, the Chief Justice of the Cape, Sir Henry de Villiers, 'is certainly not prejudiced in our favour', ${ }^{8 \mathrm{I}}$ and 'does not doubt the power of the Court to call on the military to

98I), p. 2I 5 . In Natal, fewer than ten of those convicted by martial law courts (for a variety of offences) had unexpired sentences at this time: PP I902 (Cd. 98I), p. I90. $77 \mathrm{CO}_{48} 8 / 545 / 3639$, f. 426 .

${ }^{78}$ They included the cases of J. J. Michau, Hercules Du Preez, Johannes Du Preez and Hendrik Johannes Uys.

79 Queen v. Du Preez and others (I900) I7 SCR 53.

${ }^{80} \mathrm{Du}$ Preez and his fellow detainees were released after their cases had attracted considerable attention in England. See e.g. Hansard 4th ser., vol. 79, col. $92 \mathrm{I}$ (23 February I900), col. I4II (I March I900); vol. 83, col. 574 (I8 May I900). Michau was handed over to the civil authorities but was later released: The Times, 5 February I900, p. 5; 26 March I900, p. 5; 28 March I900, p. 5; Parl. Debs., 4th ser., vol. 83, col. 392 (I7 May I900).

${ }^{81}$ Note of 3 February I900, CO $48 / 545 / 3639$, f. 426. De Villiers was critical of Chamberlain's policy towards the Boer Republics before the war and had been asked by Schreiner to go to Pretoria to urge reforms which might forestall a war. See Iain R. Smith, The Origins of the South African War I899-1902 (London, Longman, I996), pp. 273-274. He also kept in touch with Cape politicians who 
justify the detention of Br. Subjects' ${ }^{82}$ Milner was even more frank in his assessment:

Sir Henry is deeply distrusted by the English here \& has often been suspected as a traitor. I think this is quite unjust.... But he is, of course thoroughly out of sympathy with the policy of $\mathrm{H}$ M Government \& intensely Afrikander. When he, and men like him, talk of loyalty, what they mean is acquiescence in the nominal tie of the Crown between Great Britain and a country in which, under constitutional Government Afrikanders will rule the roost. ${ }^{83}$

However, by the middle of 1900 , de Villiers was in London on sick leave, and, in his absence, John Buchanan stepped in as Acting Chief Justice.

In May 1900, the court was asked for the first time squarely to address the nature of its jurisdiction in martial law, when Jan Fourie challenged his imprisonment by a martial law court for assisting the enemy. Taking a Diceyan position, his advocate, Henry Burton, argued that the law did not recognise 'a tribunal of officers' and that the military's right to punish rebels was limited to acts necessary for suppressing rebellion. The fact that the Sunnyside rebels, who were captured in the same area, had been handed over to the civilian authorities showed that there was no necessity for military punishment in this case. The application failed, after Buchanan held that the proclamation of martial law was prima facie evidence of its necessity. Quoting extensively from Chief Justice Wylde's decision in Standen v. Godfrey, ${ }^{84}$ he added that 'in the existing state of war and consequent necessity for martial law, the proclamation must be taken to interrupt and suspend the function of the civil Courts in these proclaimed districts. ${ }^{85}$ The court again refused to interfere when an application was brought on behalf of D. P. L. Gildenhuys, who was detained after having been arrested for disloyal conduct and given a preliminary examination by a resident magistrate. Rather than

opposed the war. See Eric A. Walker, Lord De Villiers and His Times: South Africa I842-I9I4 (London, Constable, I925), pp. 364-389.

${ }^{82} \mathrm{CO} 4 \mathrm{I} 7 / 286$, f. 506 (note 7 March I900).

${ }^{83}$ Milner to Chamberlain, I I April I900, in Bodleian Library, MS Milner dep. I70, f. 9I.

${ }^{8} 4$ Standen v. Godfrey (I85I) I Searle 6I at 63.

${ }^{85}$ In re Fourie (1900) I7 SCR $\mathrm{I} 73$ at $\mathrm{I} 78$. See also the reports in Cape Times, 3 May I900 and I I May I900. 
seeking a writ de homine libero exhibendo, Burton applied for the detainee to be admitted to bail, presumably with a view to having him tried or having the charges dropped. This, however, was to ask the court to recognise and control the jurisdiction of the martial law court, which it was not prepared to do. ${ }^{86}$

Buchanan reiterated his views on martial law in the case of J. H. N. Bekker and J. J. Naudé. They were arrested and charged with treason early in the war, but were kept in prison without a trial, since the authorities were awaiting the creation of the Special Court. When their application was made on I 3 July, counsel for the crown simply stated that the applicants were detained under martial law, without answering their contention that there was no necessity for martial law in the areas where they were arrested, since the enemy had been expelled and those who had joined them had been allowed to return to their farms. When Burton argued that the crown could not simply rely on the proclamation of martial law as conclusive of its necessity, Buchanan adjourned the case, treating it as an ex parte application and holding that notice had to be sent to the gaoler to provide a proper return to justify the detention. ${ }^{87}$ Three days later, he wrote to the Attorney General, Rose-Innes, pointing out that the crown's failure explicitly to reply to the allegations regarding necessity meant that there was 'no return made which would justify the court in following its previous decisions'. ${ }^{88}$ The crown took the hint. When the case returned to court, it argued that war continued to rage over the border, and (following Finlason) that martial law existed not only to put down rebellions but to prevent their recurrence. Buchanan now took the opportunity to expand on his view that martial law might still be necessary even in areas where the courts remained open and actual fighting had ceased. In his view, the fact that the proclamation of martial law had not been withdrawn in this area (though it had been elsewhere) was strong evidence of its necessity, particularly 'when it appears that the Executive is not acting arbitrarily'. Again following Standen v. Godfrey, he said that the

${ }^{86}$ Queen v. Gildenhuys (1900) I7 SCR 267 at 269. See also the report in Cape Times, I9 June I900.

${ }^{87}$ Queen v. Bekker, Queen v. Naudé (I900) I7 SCR 340 at 343.

88 Buchanan to Rose-Innes, I 6 July I 900, Rose-Innes Papers, National Library of South Africa (Cape Town), MSC 2I, Box 3, f. 307. 
process of the court was neutralised by martial law. Martial law had to be regarded as a state of affairs outside the law, with responsibility for all acts under it being taken by the authorities administering it. Any attempt by the court to intervene would lead to it justifying some acts 'which the civil law cannot tolerate'. ${ }^{89}$

Buchanan's was not, however, the only view of the matter on the Cape Supreme Court. In a lengthy judgment in the case of Bekker and Naudé, Solomon J outlined the rival views of Dicey and Finlason on the nature of martial law, and concluded that the latter's position was now 'practically exploded'. ${ }^{\circ}$ Following the Diceyan position, he held that whether or not any acts done under martial law were justifiable depended on the particular circumstances in each case; and the determination of that question could not be reserved to the military commander. Only a statute - suspending habeas corpus - could remove the court's power. Invoking the United States Supreme Court's decision in ex parte Milligan, ${ }^{9 \mathrm{I}}$ he argued that martial rule could be properly applied in 'the theatre of active military operations', but he did not consider that it was applicable in the case of these men. Despite this view of the law, however, Solomon agreed in refusing the application, though in his case it was for a strategic reason: a decision to release these men from military custody now and deal with them through ordinary criminal procedures would have required the civil authorities to put all the detained rebels through those procedures. Like everyone else, Solomon was aware that a new Special Court was about to be created which would deal with the rebels in a faster and more lenient way. It was hence in the best interests both of Bekker and Naudé and of 'the country generally' that they should remain for the time being in military custody. ${ }^{92}$

Some members of the Natal bench also took a liberal position on martial law. When Advocate W. B. Morcom of Pietermaritzburg

${ }^{89}$ Queen v. Bekker, Queen v. Naudé (I900) I7 SCR 340 at 350 . See also the report in Cape Times, I4 August I900 and I7 August I900.

90 Queen v. Bekker, Queen v. Naudé (I900) I7 SCR 340 at 355 . He may have been influenced by Robert M. King's article 'Martial Law', Cape Law Journal, vol. I7 (1900), pp. 30-42.

9I Ex parte Milligan, 7I U.S. (4 Wall.) 2, I2O-I2I (I866). On this case, see Amanda Tyler, Habeas Corpus in Time of War (Oxford, Oxford University Press, 20I7), pp. I7I-I74.

92 Queen v. Bekker, Queen v. Naudé (I900) I7 SCR 340 at 36I. 
applied unsuccessfully in April for an interdict to prevent his mail being opened under martial law, Mason J expressed the view that, while the military could take any action necessary to suppress a rebellion, the subject was entitled to demand that the powers should not be used 'recklessly, needlessly, cruelly or immoderately', and to ask the courts to 'require any persons infringing his rights to justify their action'. ${ }^{93}$ Although in Morcom's case, Chief Justice Gallwey described martial law as the rule of the General in times of emergency when civil law was set aside, by June he had come round to Mason's view. In Umbilini and Bantomo v. General Officer Commanding, in which a challenge was made to a martial law conviction, he cited the 1838 opinion of the English Law Officers that martial law did not supersede the ordinary tribunals, ${ }^{94}$ and added that the 'first and most sacred duty' of the court was to administer justice, 'not to preserve the peace of the country'. ${ }^{95}$ Alluding to Du Preez's case, he confirmed that the court had power to inquire into a case decided by a court martial, though it would not interfere if it were to be convinced that the military's actions were necessary for public safety..$^{96}$ This opinion alarmed officials in London. The assistant undersecretary of state, Bertram Cox, who considered Buchanan's view 'the more convenient for Government', ${ }^{97}$ referred the question to the Law Officers, pointing out that, if the view stated in Umbilini was correct, great difficulty would be experienced in administering martial law 'unless the extreme step were taken of forcibly suspending the sittings of the Civil Courts'. The opinion he got back was that Umbilini was 'substantially correct': a proclamation of martial law could not prevent courts from hearing habeas corpus applications. The exercise of their jurisdiction could only be 'prevented by force, as by suspension of such tribunals' ${ }^{98}$

93 W. B. Morcom v. Postmaster General (I900) 2I NLR 32 at 44. Mason's decision troubled Attorney General Bale, who drafted a memorandum on the case which was sent to the Colonial Office, which passed it to the Law Officers for information. CO I79/2II/I3I9I, f. 303.

94 William Forsyth, Cases and Opinions on Constitutional Law (London, Stevens and Haynes, I869), p. I99.

95 Umbilini and Bantomo v. General Officer Commanding (I900) 2I NLR 86 at 88-89.

${ }^{96}$ Umbilini's case was heard in July, when the court held that the conviction and sentence of the martial law court had indeed been justified: see Umbilini and another v. General Officer Commanding (I900) 2I NLR I69.

97 Note dated 4 July I900, CO I79/2 I 2/20952, f. 472.

$9^{8}$ Opinion dated I7 July I900, CO $885 /$ I 5 No. 43. 


\section{The Second Invasion, October I900-March 1902}

Once the Cape Act had been passed, the authorities began to prepare for trials in the new court. Records of preliminary proceedings were handed over by the military authorities to the Law Department in Cape Town, which decided which class the offender fell into and what the exact charges would be. ${ }^{99}$ Suspects were allowed private consultation with lawyers, and the military was instructed not to seek confessions from suspects. ${ }^{100}$ The court, made up of Justice Solomon, Justice Lange and Mr A. F. S. Maasdorp, began its work in Cape Town at the end of October. ${ }^{\text {IOI }}$ The first case it tried was not that of a rebel but of a colonial policeman charged with the murder of a Basotho farm hand. The defendant, Peter William Smith, had been part of patrol searching near Naauwpoort for farmers suspected of co-operating with the enemy. The farm hand had been sullen and unco-operative when asked to produce a bridle; and when Smith reported this to his superior officer, he was instructed to shoot him if it was not produced. This was a significant case to begin with: not only did Rose-Innes classify it as a political case within the terms of the act, but he clearly did not regard the killing as covered by the indemnity provisions. Smith was acquitted, since the court found that he had honestly believed it was his duty to obey the order given. ${ }^{\text {IO2 }}$

\section{Negotiating Martial Law}

By the time the court came to deal with cases of rebels - with its first sitting at Colesberg on 5 December ${ }^{\mathrm{IO} 3}$ - the second invasion had commenced. The invasion interrupted the court's proceedings, and it

99 Rose-Innes to Milner, 27 June I900, Rose-Innes Papers, National Library of South Africa (Cape Town), MSC 2I, Box II, f. I9; Memorandum by Rose-Innes, c. I 5 October I900, WCA AG 2053 (Part 2).

roo Circular dated I4 August I900, PP I902 (Cd. 98I), p. 39.

гог See $\mathrm{CO}_{4} 8 / 548 / 39292$, f. 226 for reports of the bail proceedings.

${ }_{102}$ The Queen v. Smith (I900) I7 SCR 56I, Cape Times, 30 October I900, 3 I October I900. The 'special treason court' dealt with a number of other similar cases, including those of J. S. Maritz and B. C. Lottering (where the defence of following orders succeeded), and of Brink and Rinke Saar and four others (where it did not), heard at Mafeking in November I90I: WCA AG 2053 (Part 2).

${ }^{103}$ See 'Cape Treason Trials', Cape Law Journal, vol. I8 (I90I), pp. I64-167; and Cape Times, I3-I 5, I7 December I900. 
was not until March that it resumed its sittings at Dordrecht. The Special Court would continue to sit throughout the war, convicting 36I Class I rebels by August 1902, and acquitting 68. ${ }^{\text {I04 }}$ However, the renewed outbreak and the accompanying extension of martial law raised the question of what was to be done with those who joined the second rebellion. ${ }^{105}$ Although, in theory, the military could now impose such penalties as it liked, Lambert reminded his masters at the Colonial Office that the aim of martial law 'is not punishment but the suppression of rebellion' and that any martial law sentences would expire at the end of the war. At the same time, he thought it highly unsatisfactory that 'rebellion can take place twice over with so slight penalties' as those imposed under the act, and wanted all the rebels to be treated as ringleaders. ${ }^{106}$ Attorney-General Rose-Innes, who considered 'the case of a man rebelling now to be much graver than that of the man who rebelled originally', regretted the limits on prosecution put in place by the Act, and now sought wherever possible to treat rebels as falling under the first class. ${ }^{107}$ However, there were limits to the applicability of the Act, since it gave the court no jurisdiction over offences committed after I2 April I90I. Just before this date, Rose-Innes therefore issued a general notice on 6 April stating that any act of treason or rebellion would henceforth be tried in the ordinary courts, which would impose the usual common law penalties. ${ }^{\text {108 }}$

The idea that this would deter rebels was not shared by the military. General Henry Settle pointed out that in districts under martial law, 'rebels well know that they are safe on hands of Dutch juries'. His view shared by Kitchener - was that '[p]rompt punishment is necessary for serious crimes and this can only be met in present state of affairs by Military Courts. ${ }^{\text {I09 }}$ Ministers referred the matter to Rose-Innes, whose

${ }^{104}$ Ninety-one were still awaiting trial, and in sixty-two cases, the Attorney General still had to decide whether to prosecute. He had declined to do so in I27 cases: $\mathrm{CO}_{48} 8 /$ 564/4035I, f. 7I9. Returns were regularly made of the statistics.

${ }^{105}$ Fifty-four rebels were captured between January and I 2 April I90 I: Shearing, 'The Cape Rebel', p. I47.

${ }^{106}$ Minute 5 February I90I, CO 48/55I/4374, f. I 84.

${ }_{107}$ Rose-Innes to C. Southey, 20 March I90I, Rose-Innes Papers, National Library of South Africa, Cape Town, MSC 2 I, Box I I, Letter Books, vol. 6, f. I I 2.

${ }^{108}$ PP 1902 (Cd. 903), enc. in No. Io, p. I2.

${ }^{109}$ Telegram I I April I90I, Cape Archives, GH 35-83. See also Edwin Tennant's report of I3 April I90I in CO 48/552/I6435, f. 287. 
view of martial law (expressed to Milner at the beginning of the year) was 'I hate the thing; it is abhorrent to me.' While he was prepared to accept martial law insofar as it was necessary for military operations, 'I cannot without violating my own idea of what is constitutionally right $\&$ wrong agree to its being applied where there is no disturbance $\&$ where it is not required for Military operation. ${ }^{\text {I } 10}$ However, in the memorandum drawn up for ministers on I 6 April, Rose-Innes agreed that in areas where civil courts, though nominally open, were in practice unable to deal with cases of treason and rebellion, the graver cases - involving only offences directly endangering the armed forces - could be tried in military courts, provided certain conditions were laid down to ensure a fair trial. Rose-Innes also insisted that Kitchener should give notice that only offences committed thereafter would be tried by military courts, to avoid a clash with the policy of trying rebels before the special court. ${ }^{\text {II }}$ A notice, drawn up by Richard Solomon (now legal adviser to the Transvaal administration), was accordingly issued on 22 April, stating that those who took up arms or actively assisted the enemy or committed any act which endangered the safety of the King's army or subjects after this date would be tried by courts martial. ${ }^{\text {I } 2}$

Although Kitchener initially claimed the right to try any rebel in martial law courts - considering the Cape Act to be 'a local arrangement' which had not 'in any way' abrogated military jurisdiction in proclaimed districts - he agreed by the end of August not to allow martial law trials for offences committed before I2 April. ${ }^{\mathrm{II} 3}$ For his part, Prime Minister Sprigg confirmed 'that necessary steps will be taken to ensure continuance of sentences of imprisonment passed by Courts Martial until such time as confirmation of the same has been obtained by an Act of the

i ${ }^{\circ}$ Rose-Innes to Milner, I January I90 , Rose-Innes Papers, National Library of South Africa (Cape Town), MSC 2I (Box II), f. 86.

${ }^{11}$ PP 1902 (Cd. 903), enc 2 in No. II, p. I3.

${ }^{112}$ PP I9O2 (Cd. 903), enc. 6 in No. II, p. I 5.

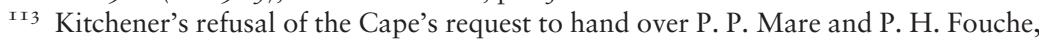
who had surrendered at the beginning of March, but been tried by a martial law court in the middle of July, led to a dispute which was resolved by late August (letting the military sentence stand): Kitchener to Governor, 25 July I90I, CO 48/553/ 28939, f. 53 I; Legal Adviser, Pretoria to Attorney General, Cape Town, 26, 28 July, 30 August I90I, WCA AG 209I (Part 2). 
Legislature'. ${ }^{I 4}$ As a result of these developments, rebels could now be dealt with in one of three ways. Those who committed offences before I2 April would be tried before the Special Court, which had given no sentences in excess of five years. Those who committed an 'aggravated form of treason' in martial law areas would be tried by courts martial, which might inflict the death penalty. For those who did not fall into either category, there could be a trial before the civil courts. ${ }^{\text {II }}$ A political compromise thus generated a hybrid system of martial law, where the court before which a rebel was tried might be determined by the date of his offence. Instead of this martial law regime being one of sheer lawlessness or executive will, it was the product of negotiations which had to satisfy the constitutional expectations of a responsible government's ministers.

Negotiations between the civilian and military authorities over the nature of martial law can also be seen in other areas. Under the Martial Law Regulations which were issued in May I90I, magistrates were recognised as having a dual jurisdiction, with powers to deal with ordinary crimes, as well as powers to deal summarily with breaches of martial law regulations as agents of the military. ${ }^{116}$ The Regulations also allowed officers to arrest without warrant any persons suspected of assisting the enemy, exciting disaffection or disturbing the peace. In such cases, evidence against the suspect was to be collected as expeditiously as possible, with preliminary examinations taken either before the officer administering martial law or before a magistrate, with a view to a trial. These Regulations - which 'which met with the concurrence of the Attorney-General's office' ${ }^{\text {II }}$ - sought to map out a quasi-judicial procedure for martial law trials, and provided for co-operation between civilian and military officers. In practice, there were numerous complaints from the civilian authorities about the heavy-handed application of martial law, ${ }^{\mathrm{II} 8}$ as a result of which the arrangement was modified in

\footnotetext{
${ }^{114}$ Hely-Hutchinson to Chamberlain, 27 May I90I, CO 48/552/I 8365 , f. 844.

${ }^{115}$ Note by Lambert, I3 April I90I, CO/48/552/16380, f. 2 I 9.

${ }^{116}$ PP I902 (Cd. 98I), pp. 46-49; cf. PP I90I (Cd. 547), enc. 3 in No. 36, p. 3 I. See further Keith Surridge, 'Rebellion, Martial Law and British Civil-Military Relations: The War in Cape Colony I 899-1902', Small Wars \& Insurgencies, vol. 8:2 (1997), pp. 44-45.

${ }^{117}$ Wynne to Hely-Hutchinson, I9 September I90I, CO 48/554/3580I, f. 586.

${ }^{\text {I } 8}$ See the letters from Rose-Innes to Settle, I4 September I90I, in Rose-Innes Papers, National Library of South Africa (Cape Town), MSC 2 I (Box I I), f. I7 I, and I4, I9, 20 December I90I WCA AG 209I (Part 2).
} 
December I90I, when twelve military Administrators of Martial Law were appointed in specified areas, each of whom would use the local resident magistrates as a Deputy Administrator, to deal with minor matters (such as the regulation of food supplies). ${ }^{\text {II } 9}$

The fact that the extent and operation of martial law could be a matter of negotiation between the civilian and military authorities became particularly evident in August I90I, when the military sought to extend martial law to the Cape ports. The desire to do so was driven by intelligence reports that 'undesirables' were returning to the Cape in private ships, and that a political network existed there which aimed to foster a rebellion in the Western Cape. ${ }^{\mathrm{I} 20}$ Ministers reacted unenthusiastically to this proposal, unconvinced that there was any threat which the local police force could not deal with, and afraid that martial law would bring business to a standstill. ${ }^{\mathrm{I} 2 \mathrm{I}}$ Faced with these rival pressures, Hely-Hutchinson (who had replaced Milner as Governor of the Cape in March) began to negotiate, asking Kitchener to agree to use martial law powers for specified limited purposes only, and proposing to give ministers a written undertaking that, if they were used for any other purposes, he would repeal the proclamation on their request. ${ }^{\text {I22 }}$ While Kitchener was prepared to agree to 'having martial law for certain definite purposes only', ministers unanimously rejected the proposal. ${ }^{\mathrm{I} 23}$ 'We cannot work Martial Law on even terms with the Military', Rose-Innes told the Governor: 'Either they or we must be in front. I am not going to ride behind.' ${ }^{\text {24 }}$ Ministers felt that a modified martial law was an impossibility: once it was proclaimed, it would override civil law in

I19 Circular 'Martial Law Administration' (G. K. Cockerill), I December I90I, PP I902 (Cd. 98I), pp. II6-I I7.

${ }^{\text {I } 20} \mathrm{O} 879 / 73 / 2$, No. I79, p. I7I; enc. I in No. 232, p. 210 ; enc. 2 in No. 263 , p. 298 . See also John S. Galbraith, 'British War Measures in Cape Colony, I900-I902: A Study of Miscalculations and Mismanagement', South African Historical Journal, vol. I 5:I (1983), pp. 77-80; and Surridge, 'Rebellion, Martial Law and British CivilMilitary Relations', pp. 50-54.

${ }^{\text {I2I In }}$ particular, Sprigg did not want the 'Supreme Court of the country and the principal public offices of the Colony within an area under the control of the Military': CO 879/73/2, enc. 4 in No. 218, p. I99.

${ }^{\text {I22 }}$ Hely-Hutchinson to Milner, 3 I August I 90 I, $\mathrm{CO} 48 / 554 / 34826$, f. 4 I; see also CO $879 / 73 / 2$, No. I 86 , p. I73.

${ }_{123}$ CO $879 / 73 / 2$, encs. I and 2 in No. 232 , pp. 2 IO-2II; No. I96, p. I 85.

${ }^{\mathrm{I}} 24 \mathrm{CO} 879 / 73 / 2$, No. 233, p. 2 I3 2 
any case of conflict. ${ }^{125}$ They also insisted that the responsibility for proclaiming martial law rested with them, and that they would not do so until satisfied of its necessity. ${ }^{\mathrm{I} 6}$

At this point, civil-military relations were plunged to a new low when Kitchener sought to force the ministry's hand by threatening to impose a cordon around the Cape ports, and to divert all non-military vessels to Durban. Facing a ministerial crisis, Hely-Hutchinson protested to Chamberlain, who responded with reassurances that no action would be taken without first consulting the Cape government. ${ }^{\mathrm{I} 27} \mathrm{He}$ realised that, without a government in the Cape, indemnity legislation would have to be passed in London, where its opponents would argue that 'ministers were driven from office in defending their constitutional rights from the lawless invasions of the military $\&$ of the Imperial Govt. ${ }^{\text {I28 }}$ Great efforts were now made to put an innocent gloss on what Chamberlain called Kitchener's 'stupid blunder', and to persuade Sprigg to consider the 'position in which Cape Colony would be placed as a member of Empire in case of request refused'. ${ }^{29}$ As a sweetener, the army proposed setting up a Board of Administration of Martial Law in the Cape, composed of both civilian and military elements, which would investigate any complaints against martial law. ${ }^{\mathrm{I}} \mathrm{O}$

The matter was finally resolved when Sprigg met Kitchener and Milner at the beginning of October in Pretoria and agreed the terms on which martial law would be extended to the Cape. Under the agreement, the military were given the right of censorship - to be exercised with as little inconvenience to the public as possible - and were authorised to impose restrictions on undesirables. Control of all works at the ports was to remain in civilian hands, though the military were empowered to appoint officers to supervise the examination of cargoes. The agreement also stipulated that there should be no martial

${ }^{125} \mathrm{CO} 879 / 73 /$ I, No. 76I, p. 23 I. ${ }^{\text {I26 }}$ CO 879/73/2, enc. I in No. 24I, p. 224.

${ }^{127} \mathrm{CO} 879 / 73 /$ I, No. 747 , p. 226; No. 75 I, p. 228; No. 78 o, p. 239; CO 879/73/2, No. 207, p. I89; No. 225, p. 207.

${ }^{128}$ Note by Lambert, I9 September I90I, CO 48/554/32906, f. 409.

${ }^{2} 29$ Note by Chamberlain, 22 September I 90I, CO 48/554/33208, f. 5 I 5 ; CO 879/73/I, No. 774, p. 237. Sprigg retorted that 'the best means of maintaining the Empire in its supreme position is to accept the advice of those who have spent the best part of their lives in the Colony which is their home': CO 879/73/2, enc. in No. 262, p. 297.

${ }^{\text {I30 }} \mathrm{CO} 879 / 73 / \mathrm{I}$, No. 784 , p. 24I. 
law courts for British subjects at the Cape ports. No subject was to be arrested by the military without an affidavit charging him with a crime, for which he would be tried before the Resident Magistrate by ordinary law, unless the Attorney General directed otherwise. ${ }^{\text {I3 }}$ Following this agreement, on 9 October, martial law was extended to the ports, and Regulations were issued for its administration in these areas. ${ }^{\mathrm{I} 32}$ Once more, the parameters of martial law had been sketched out through a process of constitutional negotiation between the civil government, the imperial authorities and the military.

At the same time, there remained tensions between the civilian and military authorities. By September, Rose-Innes had come to the view that one effect of Kitchener's April proclamation had been 'to diffuse throughout all the ranks of those engaged in the administration of Martial Law an idea that they can go much further and be much more rigorous than they were before'. He now regretted that the government had 'consented to allow the more serious political offences to be tried by Military Courts'. ${ }^{133}$ Sentences imposed by martial law courts were much more severe than those imposed by the treason court: by the end of the first week in September, fourteen rebels had been executed. ${ }^{\mathrm{I} 34}$ Protests were made both in Britain and at the Cape, after three rebels were hanged in their home towns, with locals being made to watch the executions. ${ }^{\mathrm{I35}}$ In response, Lord Stanley explained that this had been simply a 'single instance', to show that the sentences imposed by martial law courts would really be carried out. ${ }^{136}$ Further executions followed, albeit not in public.

I3 I CO 879/7 I/4, enc. in No. I 56, p. 2 I I. The Resident Magistrate would also deal with breaches of martial law regulations by subjects, acting as deputy of the commandant.

${ }^{132}$ Hely-Hutchinson to Chamberlain, 9 October I901, PP I902 (Cd. 903), p. 89; PP I902 (Cd. 98I), p. I I I.

${ }^{133}$ Rose-Innes to R. Solomon, 3 September I90 I, Rose-Innes Papers, National Library of South Africa (Cape Town), MSC 2I (Box I I), f. I48.

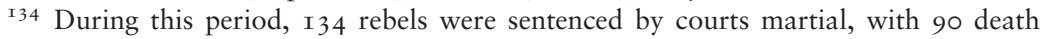
sentences being imposed. In forty-two of these cases, the death sentence had been commuted, while in fourteen more, the sentence awaited confirmation: CO 879/7I/ 4 , enc. in No. I25, p. I60.

135 They were Frederick Marais, Johannes Petrus Coetzee and Cornelius Classen. Shearing, 'The Cape Rebel', pp. I 53-I 54; and CO 879/73/2, No. I $50 \mathrm{~A}$, p. I44. The ministry protested that the compelled involvement of civilians might implicate them in a form of procedure over which they had no control: Minute of Ministers, I9 July I90I, WCA AG 2053 (Part I).

${ }^{136}$ See Parl. Debs., 4th ser., vol. 99, cols. 272-273 (9 August I90I). See also Shearing, 'The Cape Rebel', pp. I 55-I 56. 
More protests followed over the heavy-handed way in which martial law was being implemented. Rose-Innes felt that commandants were taking action quite outside the printed instructions contained in the Regulations. He raised a particular concern in early September that a number of influential citizens from Paarl and Ceres were being detained by the military in civilian prisons for long periods with no investigation of their cases. ${ }^{\mathrm{I} 7}$ The matter led to a bad-tempered clash with the Chief of Staff, Colonel Arthur Wynne. ${ }^{{ }^{3} 8}$ In Rose-Innes's view, it was 'one of the essentials of the most ordinary justice that a man should know on what ground he is detained'. ${ }^{\mathrm{I} 9} \mathrm{He}$ also pointed out that the government would have to secure an indemnity for the military, and that to do this they would have to be 'in a position to assure the House that justice has been done in each case'. ${ }^{\mathrm{I}}{ }^{\circ}$ Although Wynne conceded that it was wrong to commit people to prison with no charges being made, he defended the detentions, arguing that Paarl and Ceres were hotbeds of disaffection, 'ripe for active rebellion'. ${ }^{\mathrm{I} I \mathrm{I}} \mathrm{He}$ also considered it necessary 'to check any tendency to control the administration of martial law, not according to the discretion of responsible military officers, but according to the views of the Attorney General'. ${ }^{\text {I42 }}$ In Wynne's view, commandants were solely responsible for the execution of martial law, and it was the duty of magistrates to assist them, and not 'to pry upon their actions'. ${ }^{\mathrm{I} 3}$

Clearly resentful of being taken to task by the lawyer, Wynne responded with a lengthy memorandum explaining the difference between martial law and civil law. In times of war, he argued, the welfare of the community had to take priority over the rights of individuals. At such times, arrests had to be made on the basis of

I37 CO 879/73/2, No. I88, p. I74; enc. I in No. 233 , p. 2 I 4 .

${ }^{1} 38$ Wynne - who resented the fact that the Attorney General had raised the matter with Kitchener's legal adviser - accused him of acting without honour or justice: CO $879 /$ $73 / 2$, enc. $8(\mathrm{~L})$ in No. 26I, p. 29I at p. 292.

${ }^{139} \mathrm{CO} 879 / 73 / 2$, enc. 6(A) in No. 26I, p. 279 at p. 28I. Cf. James Rose-Innes, Autobiography, ed. B. A. Tindall (Oxford, Oxford University Press, I949), p. I93.

${ }^{\mathrm{r}} 4 \circ \mathrm{CO} 879 / 73 / 2$, enc. 2 (A) in No. $26 \mathrm{I}$, p. 272 at p. 263 ; cf. CO $879 / 7 \mathrm{I} / 4$, enc. 4 in No. $46, \mathrm{p} .42$.

I4I $\mathrm{CO} 879 / 73 / 2$, enc. $8(\mathrm{~L})$ in No. 26I, p. $29 \mathrm{I}$ at p. 292; enc. 5 in No. $26 \mathrm{I}$, p. 277.

${ }^{142} \mathrm{CO} 879 / 73 / 2$, enc. 7 in No. 23 , p. 2 I9.

I43 CO $879 / 73 / 2$, enc. 2 (B) in No. 26 I, p. 274. 
suspicion, drawing on a system of intelligence which would be exposed and undermined if any case came to court. ${ }^{\mathrm{I} 44}$ Reading over the exchanges, Fred Graham thought Wynne's memorandum to be 'excellent' and minuted that Rose-Innes had 'adopted an unreasonable position ... which would defeat the very object of martial law'. He also mused that the correspondence revealed how ministers in a self-governing colony might obstruct operations against an enemy, if they chose to stand on their legal rights. ${ }^{\mathrm{I} 45}$

\section{Legal Challenges}

The cases which had attracted Rose-Innes's attention soon found their way into the Supreme Court. The first case was brought by D. F. Marais, a Notary Public and attorney at Paarl. Marais was arrested on I 5 August by the Chief Constable, who had no warrant and did not know the cause of the arrest. Two days after his arrest, a report in the Cape Times alerted Rose-Innes to the matter, leading him to telegraph the magistrate at Paarl asking for full particulars of the charges. In reply, he was informed that the arrests were made on military authority and that there were no affidavits against them. ${ }^{\mathrm{I} 46}$ Two days later, Marais and four others arrested at the same time were moved to Beaufort West, 250 miles away. After nine days' incarceration in a 'badly ventilated, small, unbearably hot' prison, Marais asked to see the local commandant, but was refused. ${ }^{\mathrm{I}}{ }^{7}$ Meanwhile, a firm of attorneys in Cape Town took up the case of the detainees. However, General Wynne was not prepared to allow the men to communicate with their lawyers or family, or even to answer their inquiries himself; but sharply told the Law Department at the Cape that he was 'responsible to his Military Superiors only for the action he takes under Martial Law'. ${ }^{\mathrm{I}}{ }^{8}$

Although Marais was not told of any charges against him, he was visited in prison on 27 August by an intelligence officer named Burton.

${ }^{1} 44 \mathrm{CO} 879 / 73 / 2$, enc. 2 in No. 263 , p. 298.

${ }^{4} 45$ Note I 5 November I90I, CO 48/554/36629, f. 682.

${ }^{146}$ Telegram dated I7 August I90I, WCA AG 205 I.

${ }^{147}$ D. F. Marais, Statement of Grievance (March I902), WCA AG 37I4.

${ }^{148}$ Major W. P. Braithwaite to Secretary to Law Dept, 27 August I90I, WCA AG 204I (Paarl Disturbances). 
After producing a flask of whisky, he showed Marais a letter which alleged that the attorney knew of stocks of ammunition hidden in the Swartberg mountains, and that, if he would locate them, he would be 'alright'. Marais flatly denied having any such knowledge: 'I now decided to petition the Court, as I feared that the strain of gaol life would prove too much for me.' ${ }^{49}$ Notice of the petition to release him was served on Wynne on 2 September, who submitted an affidavit on the first day of the hearing, which stated that he had ascertained that there was a prima facie case against Marais and the other detainees, and that there were military reasons for his removal and detention. Although he was not prepared to disclose any charges, he confirmed that they would be formally charged 'as soon as possible' and would either be acquitted or be detained in custody following the verdict of a military court. ${ }^{150}$ When his petition was brought, Marais's advocate distinguished his case from Fourie and Bekker on the ground that (unlike them) Marais had neither been charged nor convicted by the military. Although Buchanan ACJ again declined to take notice of any acts of the military, ${ }^{{ }^{5 I}}$ he ordered a return to be made on I 2 September: for while it was common knowledge that the men had been arrested under martial law, they were being detained in a civil prison by a civilian officer, who needed to answer by what authority he held the detainee. It was the conduct of the civilians, not the military, which was of concern here.

The warrants to commit Marais and the others were issued only on 8 September, two days after the first hearing. In his draft affidavit of the next day, the civilian gaoler at Beaufort West, Henry Risk, stated

The reason I allowed these prisoners to be placed in gaol without any warrant is because in a previous case, viz that of Gert Visagie $\&$ others, the men were placed in Gaol against my wishes and by force and an armed guard placed over the Awaiting Trial yard with orders to take no orders either from the Resident Magistrate or myself. ${ }^{\mathrm{I}}{ }^{2}$

${ }^{149}$ D. F. Marais, Statement of Grievance (March I902), WCA AG 37I4. In fact, his petition was submitted by his lawyers, who had not been allowed to communicate with Marais.

${ }^{150}$ Marais v. The General Officer Commanding the Lines of Communication and the Attorney General [190I] I 8 SCR 301 at 304 (dated in WCA AG 37I4).

${ }^{\text {I5I }}$ He noted that civil courts lacked the power to enforce orders against the military: Cape Times, 7 September I90I (also 2 CTR 469).

${ }^{152}$ WCA AG 204 I (Paarl Disturbances). On Attorney General Ward's instructions, this phrase was omitted from the submitted affidavit. 
The warrant stated that the men were committed under Martial Law Regulation I4(2), for inciting others to take up arms against the king, but no substantive details of the charges were provided. When the case returned to court, it was Rose-Innes himself who opposed Marais's release on behalf of the crown, arguing that the detainees were in the custody of the civilian gaoler at the request of the military. Although he had strongly condemned this practice in his correspondence with military officials, Rose-Innes defended it in public. Buchanan ACJ rejected the application, holding as sufficient the formal return that the gaoler held Marais as an officer under the control of the military, acting on military instructions in a martial law area. He added that it had been established in previous cases that the proclamation of martial law at Beaufort West was justified by its necessity, which meant that the onus was on the applicants to establish that this necessity no longer existed. As for Adv. Currey's argument that there was no necessity for martial law at Paarl, where Marais had been arrested, Buchanan took the view that this would be relevant only if he were still being held there. Refusing to look into the charges on which Marais was being held, he also repeated his earlier view that 'while martial law was paramount the civil authority would stay its hand.' ${ }^{\text {I53 }}$

Shortly after this decision was handed down, the court heard the very similar case of Dr R. J. Reinecke. One of only two medical doctors in Ceres, he was removed by the military to Malmesbury (fifty miles away) on 28 August. One month later, his wife lodged an application for his release, pointing out that the ordinary courts exercised undisturbed jurisdiction in both towns. This time, Rose-Innes did not appear for the government, but sent his deputy, Dr Ward KC, to argue the case. Although the case looked identical to Marais's, on this occasion Buchanan ACJ ordered the detainee's release, on the ground that he was being held by civilian gaolers, rather than being in military custody. 'The gaoler, as a Civil servant of the law, has no right to hold a prisoner on the order of anybody except a duly constituted Civil officer of the Crown', he ruled, 'and as he had no warrant from any such officer, he is not entitled to keep custody of this person.' ${ }^{\text {I54 }}$

\footnotetext{
${ }^{153}$ Marais v. The General Officer Commanding the Lines of Communication and the Attorney General [I90I] I 8 SCR 30I at 309-3 IO.

${ }^{15} 4$ Reinecke v. Attorney-General and Others [I90I] I 8 SCR 349 at 354.
} 
Officials at the Cape and in London were both shocked and puzzled by this decision, the real grounds for which Buchanan later explained to Hely-Hutchinson. In Reinecke's case, it had not been stated in the affidavits for the crown that the detainee was being held in military custody. Although in Marais's case, Buchanan was prepared - at a stretch - to accept a verbal statement from the Attorney General that the detainee was being held in military custody, he was not prepared to accept such a statement from his deputy. ${ }^{\mathrm{I} 55}$ If Buchanan was hereby asserting the need to comply with legal formalities, officials in London were unimpressed with his alighting on a 'technical \& foolish point'. 'The point of substance is that the Court interfered with the exercise of martial law which it is unwise of a Court to do', Bertram Cox minuted, 'If the soldiers had declined to permit the release the Court would have been helpless $\&$ in an undignified position. ${ }^{\text {I56 }}$ In fact, Reinecke was not released: the military authorities responded by taking over the prison in Malmesbury and appointing the civil gaoler to act in a military capacity. A circular was sent to all Resident Magistrates to inform them that all gaols were to be considered as under the orders of the commandant. ${ }^{\mathrm{I} 57}$

'[A]ggrieved by the decision of the Supreme Court', Marais decided to appeal to the Privy Council. ${ }^{158}$ The court which heard his application for leave to appeal on 5 November was made up of seven judges: Lord Chancellor Halsbury, Lords Macnaghten, Shand, Davey, Robertson and Lindley, and Sir Henry de Villiers. It was clear from the exchanges that the different judges on the panel did not view martial law in the same way. Lord Davey - who had a number of liberal South Africans friends including de Villiers ${ }^{\mathrm{T} 59}$ - seemed particularly

${ }^{155}$ Hely-Hutchinson to Chamberlain, 2 October I90I, CO 48/554/36639, f. 9 I 5.

${ }^{156}$ Minute, 22 October I90I, CO 48/554/36634, f. 838.

${ }^{157}$ Hely-Hutchinson to Chamberlain, 2 October I90I, CO 48/554/36634, f. 839. Reinecke was released on parole on 25 October (after a new military officer took charge at Malmesbury), pending trial by a martial law court. After a review of his case in January found there was no evidence against him, he was given permission to go to Europe (but not to return to Ceres): see his account in The Times, 27 March I902, p. 6.

${ }^{158}$ Marais, Statement of Grievance, WCA AG 37I4. Marais's decision to appeal led Chamberlain to advise Hely-Hutchinson to 'defer further action' in relation to the charges against him until its decision had been handed down: Chamberlain to HelyHutchinson, I6 September I90I, CO 48/554/34826, f. 303.

159 After hosting John X. Merriman to dinner in March I90I, Davey told de Villiers that he was 'so depressed and so different from what he was when I had the pleasure of 
sympathetic to Sir Richard Haldane KC's arguments for Marais, and argued that the Petition of Right forbad the use of martial law courts when the civil courts were open. ${ }^{160}$ By contrast, Lords Halsbury and Shand inclined to the view that, in wartime, it was for the military to judge the necessity for martial law, and that, once it had been proclaimed, they could determine the area over which it applied. In Halsbury's view, '[i]f the public safety and that of the realm render it necessary to supersede the ordinary law you are not bound in every individual case to prove the necessity or even to state the charge.' Furthermore, ' $[\mathrm{t}] \mathrm{he}$ courts are not open when resort to them would be unsafe to the King's authority. ${ }^{\text {I6I }}$

The petition was rejected, with three members of the court reported to be in the minority. The customary single judgment of the judicial committee was delivered by Halsbury on I 8 December. The Lord Chancellor dismissed the argument that martial law courts had no jurisdiction if the civil courts were open: the fact that they were open for some purposes did not mean that war was not raging. Indeed, Halsbury stated - incorrectly - that Marais's own affidavits had made it clear that war was raging. ${ }^{162}$ ' $[\mathrm{N}] \mathrm{o}$ doubt has ever existed that where war actually prevails the ordinary Courts have no jurisdiction over the action of the military authorities.' ${ }^{163}$ The division of opinion on the bench became public in March 1902, in a debate in the House of Lords, during which Halsbury did not shy away from defending his position: 'The real English of the matter is that if you are at war there is and there can be no constitutional liberty at all. ${ }^{164}$ By contrast, Lord Davey insisted that it did not follow that because there was a state of war, 'persons are to be deprived of their constitutional rights ... and the whole jurisdiction of the courts handed

meeting him at the Cape'. Davey to de Villiers, 2 April I90 I, De Villiers Papers, National Library of South Africa, MSC 7 (Box 8).

160 Manchester Guardian, 6 November I90I, p. 6.

${ }^{161}$ Manchester Guardian, 6 November I90I, p. 6.

${ }^{162}$ D. F. Marais v. The General Officer Commanding the Lines of Communication and the Attorney General of the Cape Colony [1902] AC I09 at II4. The petition and affidavit spoke only of Marais's arrest and removal by the military and made no explicit mention of a state of war.

${ }^{163}$ D. F. Marais v. The General Officer Commanding the Lines of Communication and the Attorney General of the Colony [1902] AC I09 at I I 5 .

${ }^{164}$ Parl. Debs., 5th ser., vol. I05, col. I39 (I7 March I902). 
over to military tribunals set up for the purpose'. ${ }^{165} \mathrm{He}$ regarded Halsbury's view as unconstitutional since it seemed to recognise a prerogative power to suspend the ordinary courts, which was equivalent to the French state of siege. ${ }^{\text {I66 }}$

The decision received mixed reviews in the Cape press. ${ }^{167}$ It was also debated by a number of jurists in the Law Quarterly Review. They included Frederick Pollock, who defended a Diceyan position, but felt that the judicial committee had come to the correct decision, since the effective radius of warfare was much broader in the modern age, and that 'the absence of visible disorder and the continued sitting of the courts are not conclusive evidence of a state of peace. ${ }^{\text {I68 }}$ By contrast, 'A Jurisconsult' writing in The Speaker lambasted 'the Liberty of the Subject according to Lord Halsbury', arguing that the court had ignored the central point that Marais - like George Gordon before him in I 865 - had been moved to a distant place where the civil courts were closed, something which violated Lord Carnarvon's rules. ${ }^{169}$ Two months after the decision had been made, it was also discussed judicially in Ireland, in a civil suit brought by the District Commissioner of Kintampo in the Northern Territories of the Gold Coast against a senior military officer who had detained him during a time of rebellion. Addressing the jury, Chief Baron Palles said that, while he respected the Privy Council's decision, he was not prepared to accept 'that the law now is that in a country in which a state of war or rebellion exists, any act done by any officer serving in the forces of the Crown, whether it is or not one of military necessity, is not cognizable by the ordinary courts of justice'. Nor was he prepared to '[lay] down as law that if a rebellion exists in any part of a country, then the entire country is to be subjected to the license of all the officers and forces of the Crown'. ${ }^{170}$

${ }_{165}$ Parl. Debs., 5th ser., vol. I05, col. I48 (I7 March I902).

${ }^{166}$ Parl. Debs., 5th ser., vol. I05, col. I49 (I7 March I902). See also Parl. Debs., 5th ser., vol. I06, col. II 58 (24 April 1902).

${ }^{167}$ See the Cape Times, 20 December I900 and the press cuttings in WCA AG 37I4.

${ }^{168}$ F. Pollock, 'What Is Martial Law?', Law Quarterly Review, vol. I8 (I902), pp. I $52-158$ at p. I 57 . The other articles were by H. Erle Richards, 'Martial Law', ibid., pp. I33-I 42 and Cyril Dodd, 'The Case of Marais', ibid. pp. I43-I 5 I.

169 'The Liberty of the Subject According to Lord Halsbury', The Speaker, 28 December I90I. See also the critical leader in Manchester Guardian, I9 December I90I, p. 5 .

170 Rainsford v. Browne (I902) 2 New Irish Jurist and Local Government Review, I79 at I86. 
The decision to detain men like Marais was motivated by a desire to control potential political intrigue in the Western Cape, rather than being driven by the kind of military necessity which (as has been seen) men like Rose-Innes were prepared to accept as a justification for martial law. Colonial officials had long been suspicious of the loyalty of towns such as Paarl, whose educated inhabitants 'cherish the dreams of an African Dutch state'. ${ }^{\text {II }}$ By the middle of I90I there was a perception that it would take very little for local Bond politicians to rebel. ${ }^{172}$ Indeed, in July, the military's unreliable secret agent, Capt. C. Ross, reported a claim that 'every Bond member was ready to rise'. ${ }^{173}$ It was in this context that men like Marais - whose father had been a Bond Member of the Cape Legislature for Paarl until I $900-$ came under suspicion. In upholding his detention, both the Privy Council and Pollock accepted the military's general suspicions as demonstrating the necessity for his detention, rather than RoseInnes's more rigorous test.

Sir Henry de Villiers returned to resume his duties on the Cape bench after the judgment in Marais had been handed down. It soon became clear that he would take a narrow view of its meaning. He was given the first chance to express his view in April I902, when he heard the cases of J. W. Malan and J. D. Bruyns. Both men had been detained in Calvinia on charges of treason, for offences committed before I 2 April I90I. In both cases, the Attorney General had instructed the magistrates that they were to be dealt with as Class 2 rebels, who were entitled to be released. However, both men were moved by the military in November I90 I to Clanwilliam prison. They subsequently escaped from prison and were sentenced after being recaptured to six months' imprisonment with hard labour by the Resident Magistrate of Clanwilliam. In his decision, de Villiers acknowledged the Privy Council's ruling that, during wartime, the military could not be held liable for any illegal acts committed. However, he regarded the case before him as a civilian rather than a military one, for the magistrate

${ }^{171}$ Lambert note, 20 Nov I 899, CO 48/543/34343, f. 493; cf. Milner Diary of events, I 6 January I90I, $\mathrm{CO}_{48} 8 / 55$ I/4322, f. I 46 .

${ }^{172}$ In six border districts which rebelled, forty-eight out of seventy-three Bond officials were convicted of treason, while eight more had absconded. Hely-Hutchinson to Chamberlain, 2 June I902, CO 48/561/25265, f. 250 ; PP I902 (Cd. 903), p. I I 9.

${ }^{173}$ Report, 8 July I90I, CO $48 / 554 / 36637$, f. 89 I. 
had sentenced the men under provisions of an ordinary statute, and not under military regulations. Furthermore, de Villiers held that the decision to classify them as Class 2 rebels entitled them to be released from prison in Calvinia, so that the removal of the men to Clanwilliam without a proper warrant was unlawful. In passing, the Chief Justice criticised the use of magistrates as Deputy Administrators of Martial Law, which he saw as 'fatal to the due administration of justice'. ${ }^{174}$

De Villiers's decision irritated the Cape's Attorney General T. L. Graham. The Chief Justice's view on the rights of Class 2 rebels to an immediate release did not reflect the understanding which had hitherto been acted on by the Law Department, and he worried that those who had not been released might commence civil actions. He therefore wrote to all Resident Magistrates instructing them to release any remaining Class 2 rebels; and advised the military to re-arrest under martial law powers any of them they considered necessary to keep in detention. In London, Bertram Cox noted that 'the attitude of the Cape Courts shows that we must take action as to the prisoners under martial law as soon as possible by removing them or by legislation.' ${ }^{\text {'75 }}$

De Villiers had another opportunity to express his views on martial law in July, when Bailly van Reenen and Daniel van Reenen challenged their convictions for breaching martial law regulations by two magistrates, one in Durbanville and the other in Malmesbury. The men were tried for breaching a regulation which forbade people from entering or leaving the district of Malmesbury without a permit, which they had contravened by moving two mules in the early hours of the morning from one district to the other. Applying the rule in Marais, de Villiers held that the court could not interfere in the decision of the Durbanville court, since the Resident Magistrate there had purported to act in his capacity as Deputy Administrator of Martial Law. At the same time, he took the occasion to observe that 'it cannot be assumed that Martial law will be maintained any longer, in view of the Privy Council's decision [in Marais] that Martial Law can only be justified by the existence of actual hostilities. ${ }^{\text {I76 }}$

\footnotetext{
${ }^{174}$ R. v. Malan and Bruyns (I902) I9 SCR I87 at I9I-I92.

${ }^{175}$ Report of T. Lynedoch Graham AG 5 May I902, CO 48/560/216 18, f. 679.

${ }^{176}$ Cape Times, I4 July I902; cf. R. v. Bailly van Reenen and Others (I902) I9 SCR 332 at 334 .
} 
Turning to the decision of the Malmesbury court, he observed that the record of that case stated that it had taken place in the 'Court of the Resident Magistrate and Deputy Administrator of Martial Law'. Insofar as it purported to be the decision of a civilian court, de Villiers held that it was amenable to review; and, as its proceedings were irregular (and a sentence imposed for an offence unknown to civilian law), its proceedings were quashed. ${ }^{177}$ As this case revealed, officials in Malmesbury had used the ordinary forms of the courts when drawing charges for breaches of martial law regulations, without deleting the words 'In the Court of the Resident Magistrate', and only sometimes adding in the initials of the Deputy Administrator of Martial Law. In response to this decision, the Administrator of Martial Law instructed them to alter the books containing the records of martial law cases, to make it appear that they had been treated only as martial law cases. The legal effect of this was considered by de Villiers in August, when a number of those sentenced at Malmesbury for breaches of martial law regulations challenged their convictions. ${ }^{178}$ De Villiers held that these cases had to be treated in the same way as Bailly van Reenen's, since he could not sanction the alteration of the record, even if authorised by a military officer.

When Bertram Cox saw the decision in Bailly van Reenen's case, he conceded that it was 'within the law' but commented that de Villiers's 'knowledge of the Marais decision was rudimentary and ridiculous.' ${ }^{\text {I79 }}$ For his part, the Cape's Attorney General thought the decision wrong, and decided to appeal to the Privy Council. The case was heard in London in December 1903. By this stage, with the war over and martial law at an end, the question was academic: but it gave the court another opportunity to clarify its view of the powers of civil courts over martial law decisions. None of the respondents was represented at the hearing, for which the Cape government secured Haldane's services. ${ }^{80}$ Once again it was Halsbury who delivered the judgment. Overturning the

${ }^{177}$ R. v. Bailly van Reenen and Others (I902) I9 SCR 332; and Cape Times, I4 July 1902.

${ }_{178}$ South African News, 29 August 1902.

${ }^{179}$ Note, 8 August I902, CO 48/563/321 I9, f. 98.

${ }^{180}$ According to Frederick Mackarness (one of the lawyers in Marais), 'The appeal is really a War Office one, $\&$ the War Office people were present instructing the petitioners' representatives.' Mackarness to de Villiers, 27 November 1902, De Villiers Papers, National Library of South Africa (Cape Town), MSC 7 (Box 9). 
Cape court's decision, he ruled that de Villiers had gone wrong in treating the documents in question as a 'record' of a court of justice, rather than simply a memorandum of the charges. The case, he concluded, was heard by $\mathrm{Mr} \mathrm{C}$. W. Broers in his capacity of deputy administrator of martial law, and not as a magistrate, so that the Supreme Court lacked jurisdiction. ${ }^{\mathrm{I}{ }^{\mathrm{I}}}$ This was a short, simple judgment, which omitted any mention of the alteration of the documents on the orders of the military. Where both the civilian and military authorities at the Cape assumed that the civil courts retained some measure of jurisdiction, the Lord Chancellor in England held to his blunt view that, so long as the proclamation of martial law was in force, all civil jurisdiction was gone. Once more, the view from London was much less Diceyan than the view from Cape Town.

\section{The Martial Law Board}

When martial law was extended to the Cape ports in October I90I, the military agreed to the creation of a Martial Law Board to deal with complaints about the administration of martial law, to be made up of three men chosen by the General Officer Commanding Cape Colony, the Prime Minister and the Governor. H. W. Just was pleased to see the Board set up to deal with complaints, since he realised that, although martial law rendered the will of the military paramount, neither the government in Cape Town nor the Colonial Office could escape 'a very grave responsibility if there are scandals or mistakes'. ${ }^{182}$ Chamberlain wanted the Board made up of practical legal men, but was insistent that Rose-Innes should not be on it, since he was 'peculiarly unfitted by his habit of mind for a position [...] where it is necessary to consider expediency and policy as well as his conscientious scruples'. ${ }^{183}$ Lewis L. Michell, the general manager of the Standard Bank, was nominated as chairman by the Governor. He clearly had no intention of rocking the boat, telling Hely-Hutchinson that he saw his task as one of helping and not hindering the military authorities. Besides discouraging frivolous grievances, he noted that not too much was to be 'made

\footnotetext{
${ }^{181}$ Attorney General for the Cape of Good Hope v. Van Reenen [I904] AC II4 at I 8 -i I9, cf. The Times, Io December I903, p. Iо.

${ }_{182}$ Note 2I November I90I, CO $48 / 555 / 38373$, f. I 5 .

${ }^{183} \mathrm{CO} 879 / 73 / 2$, No. 246, p. 240.
} 
even of substantial hardships to the individual, if clearly necessary to be inflicted in the interests of the State, which must be paramount'. ${ }^{184}$

The Board's work continued until July I902, by which point it had dealt with 542 complaints in 74 meetings. ${ }^{185}$ The largest number of complaints related to deportations, primarily those to Port Alfred. Of I4I such cases which came before the Board, it declined to intervene in 76. Thirty were 'satisfactorily adjusted' without its intervention, and only five were redressed through its recommendation, while twentynine were resolved by the intervention of peace. Most officials thought the work had been done well. Reporting to Hely-Hutchinson in December I90I, Michell stated that in the majority of cases 'complainants have suffered through some misconduct of their own, or were dealt with on reasonable grounds of suspicion'. ${ }^{186}$ Looking over the first six months of its work, Sir Montagu Ommanney (who was usually sympathetic to the military) similarly observed that the report 'does not lend much support to the allegations of hardship in the administration of martial law'. ${ }^{187}$ Others were more sceptical: as Sir Henry de Villiers told F. A. Newdigate, 'the Dutch have firmly got it into their minds that it is worse than useless.' ${ }^{\prime} 88$

When dealing with deportees, the Board's procedure was to ask the military to provide reasons why people had been deported, and to ask whether they might be allowed to return to their homes on bail. Military commanders did not react well to such requests. In January 1902, Major H. Shute, the Administrator responsible for Graaff-Reinet, explained to M. G. Apthorp, the secretary of the Board, that before anyone was sent to Port Alfred, their cases were investigated by a small committee of loyalists 'specially selected by me on account of their judicial capacity and unprejudiced minds' and by an intelligence officer; and full reports of the charges were sent to the commandant on the coast. In his view, it was very taxing to his over-worked subordinates

\footnotetext{
${ }^{18} 4$ PP 1902 (Cd. 903), No. 46, p. I I6. In November I 899, Michell urged Schreiner to extend the geographical scope of martial law, to effect a moratorium on bills of exchange: 8 November I 899, CO 48/543/34334, f. 4I3.

${ }_{185} \mathrm{CO} 879 / 77 / 3$, enc. I in No. 244 , p. 204.

${ }_{186}$ PP 1902 (Cd. 903), enc. 5 in No. 59, p. I6I.

${ }_{187}$ Minute of I 5 May I902, CO 48/560/I7300, f. 97, referring to CO 879/76/I, enc. in No. II6, p. I25; see also enc. in No. I74, p. I 88.

${ }^{188} \mathrm{CO} 879 / 74 / \mathrm{I}$, enc. in No. 99, p. 98 at p. I04. The South African News (I I October I902) described it as 'a device for evading complaint'.
} 
to have to 'furnish full reports upon fictitious accusations'. ${ }^{189}$ So irritated was he by the process that he suggested that complainants should be charged fees to make any application, and should be prosecuted for libel for any false complaints.

In practice, large numbers were deported simply for being suspicious characters without much in the way of investigation. For instance, the brothers J. J. and P. A. Erasmus were deported because 'they are the loudest talkers and the worst rebels in Graaff-Reinet, their shaving saloon being the meeting place of the disloyal section'. C. J. Olivier was described as a 'dangerous character' who could not be trusted, and who had been constantly warned for using seditious language and for jeering at those who joined the town guard. Many deportees were listed simply as being 'notoriously disloyal' or as 'very bitter and dangerous'. In some cases, men were deported because there was not sufficient evidence to charge them with breaching martial law regulations. ${ }^{190}$ In other cases, deportations were made pour décourager les autres. The Acting Resident Magistrate at Middelburg told Shute that, while nothing could be proved against a number of deportees from his area, the effect of their detention served as a 'warning to all sympathisers with the enemy' that the least assistance given by them to the rebels 'will render them liable to be deported to Port Alfred for an indefinite period'. ${ }^{\text {I9I }}$ Shute was not unsympathetic to this position, telling the Martial Law Board that 'the deportation of certain persons is not intended so much as a punishment, but as a means of keeping away from a disturbed District those who are a danger to the community at large $\&$ also as a deterrent. ${ }^{\text {I92 }}$

The military remained reluctant to allow deportees to return home even as the war entered its later stages. The Board was powerless in the face of military opposition. Its sense of its own powerlessness can be seen in its response to a complaint from three men - J. J. Hayward of

\footnotetext{
${ }^{189}$ Shute to Secretary, Martial Law Board, 3 January I90[2], WCA AG 209I (Part I).

${ }^{190}$ H. B. Davel was 'suspected of having led Theron's Commando when French's Scouts were captured, but the evidence is not sufficiently clear to warrant an indictment'. His father was fined $£_{5} 00$ for hiding foodstuffs for the enemy, and was deported when the military considered the fine insufficient. WCA AG 209I (Part I).

19I W. Richards to H. Shute, I 5 January I902, WCA AG 209I (Part I).

${ }^{192}$ Shute to Secretary, Martial Law Board, 7 February I902, WCA AG 209I (Part I).
} 
Graaff-Reinet, J. B. Rabie of Aberdeen and G. F. Smith of Jansenvillethat they had been re-arrested while on parole in Port Elizabeth and returned to Port Alfred, even though martial law had not then been in operation at Port Elizabeth. The men claimed that the military had acted illegally, since they had no power to supersede the civil jurisdiction in Port Elizabeth at that time. Hayward wanted to challenge the military's actions in court, but was unable to do so thanks to his removal to Port Alfred. After discussing the case, the Board decided not to take up the issue of the illegal action by the military: Apthorp noted that ' $\mathrm{t}$ ]he case of Dr Reinecke who succeeded in obtaining an order from the Supreme Ct for his release from gaol but who was rearrested by the military an hour afterwards is sufficient indication that these men would gain nothing by bringing up the point now. ${ }^{\text {'93 }}$ Nor was the local commander prepared to allow Hayward to return to Graaff-Reinet when he considered all the cases at the end of January.

The Board also dealt with sixty-three cases of detention. Of these, only six were redressed through the Board's intervention. ${ }^{\text {I94 Among }}$ the cases which came before the Board was that of D. F. Marais. The case was referred to them on the advice of Rose-Innes, who received a letter on I9 October I90I from Marais's wife describing his detention as 'a cruel mockery of justice'. ${ }^{195}$ The Board took it up with the military, but found Wynne unwilling to submit any papers to them relating to the case - or indeed to take any action in the case pending the decision of the Privy Council. ${ }^{196}$ The Board did not consider this to be a reason to delay their investigation: indeed, in their view, the very reason given by the Supreme Court for not intervening - that this was a matter pertaining to martial law demonstrated that it was essentially a case for them. ${ }^{197}$ The Board felt that Marais should be put on trial at once (for the breach of the martial law regulations), or else that they should be given reasons why

\footnotetext{
${ }^{193}$ Note dated 23 December I90I, WCA AG 209I.

${ }^{194}$ It declined to interfere in twenty-eight cases, while eleven were 'satisfactorily adjusted' without its intervention. CO 879/77/3, enc. I in No. 244, p. 204.

195 WCA AG 37I4.

196 Wynne to Martial Law Board, 27 October I90I, WCA AG 37 I4.

197 At the same time, they dropped hints to Mrs Marais that matters might be expedited if the case to the Privy Council were dropped. Secretary, Martial Law Board to Mrs E. Marais, 5 November I90I, WCA AG 37I4.
} 
this was not done. ${ }^{198}$ After the Privy Council's decision was made, there seemed even less reason for not proceeding with the military trial of Marais and those detained with him. Attorney General Graham told Michell, 'We shall make ourselves parties to what I am sure will be grave injustice if we stand by $\&$ consent to imprisonment of these men indefinitely, without option of bail.' ${ }^{\text {'99 }}$

On I3 December, Marais and A. B. de Villiers (who had been detained with him) were told by the Administrator of Martial Law that the charge against them was that of 'using language'; and that, since they were not 'criminals', they would be sent back to Paarl the following week. ${ }^{200}$ Four days later, de Villiers was released on bail in Beaufort West. Marais himself remained in gaol, since Wynne intended to try him in January I902, when the standing military court reached Beaufort West. ${ }^{201}$ However, the trial was postponed for lack of reliable evidence against him, ${ }^{202}$ and on I 8 February, he was released on bail and ordered to proceed to Port Alfred. From here, Marais continued to press his case to be allowed to return home, arguing that the abandonment of the charges against him amounted to an acquittal, so that Wynne was bound by his earlier statement to release him. In his view, 'my deportation to Port Alfred not as an undesirable in the first instance but following on a long term of imprisonment and the abandonment of a specific charge enhances the illegality of the action of the military authorities. ${ }^{203}$ Although the Board pressed the military on this case - asking 'whether he has not been sufficiently punished more especially as he has incurred considerable expense in connection with his application to the Privy Council ${ }^{204}$ - it was to no effect, for in the middle of May, Settle responded that it was not advisable to allow him back to an area as disloyal as Paarl. ${ }^{205}$ Marais would return home (along with the other deportees) only after the coming of peace. His experience showed that there were severe limitations to the promise of legalism implied in the publication of martial law regulations, which

\footnotetext{
${ }^{198}$ Minute dated 4 November I90I, WCA AG 37 I4.

${ }^{199}$ Wynne to Martial Law Board, 23 December I90I, WCA AG 37 I 4.

${ }^{200}$ Marais, Statement of Grievance, WCA AG 37I4.

${ }^{201}$ Graham to Michell, 23 December I90I, WCA AG 37I4.

${ }_{202}$ Settle to chair, Martial Law Board, 3 February I902, WCA AG 37 I 4.

203 Marais, Statement of Grievance, WCA AG 37I4.

${ }^{204}$ Draft letter to the General Officer Commanding, April I902, WCA AG 37 I4.

${ }^{205}$ Settle to Ebden, I 5 May I902, WCA AG 37I4.
} 
stated both that preliminary examinations had to be held and that 'all persons who directly incite others to take up arms \&c shall immediately on arrest be tried by military Court.' At the same time, his case also showed that the Board was not entirely ineffective: the persistent pressure both from the Board and from his supporters may not have enabled him to return to his home and business, but it at least induced the military to release him from custody in Beaufort West.

\section{Ending Martial Law}

After the signing of the peace of Vereeniging, the authorities had to consider how to manage the transition from martial law to peace. A policy was needed to deal both with those rebels who had been sentenced by martial law courts since April $\mathrm{I}_{90 \mathrm{OI}}{ }^{206}$ and with those who had not yet been tried. As part of the peace negotiations (which ensured that no legal proceedings were to be taken against burghers), the Boer General Jan Smuts secured terms which would protect the thousands of rebels who had joined his troops. The terms of this agreement were implemented in a proclamation issued on II June. Those rebels already in detention, as well as those who had surrendered before Io July 1902, would be disfranchised, but would suffer no other punishment if they formally acknowledged themselves to be guilty of High Treason before a Resident Magistrate. The offer did not extend to those who held official positions in the colonial government or who had been commandants in the rebel forces, who were to be tried for treason, but were not to be sentenced to death. ${ }^{207}$ The offer thus mirrored the bifurcated treatment of Class I and Class 2 rebels under the Act of 1900. By I July, 2,5 I I rebels had surrendered. As Lambert noted, the final surrender of the rebels would make the continuation of martial law difficult. ${ }^{208}$ By the end of August, over

${ }^{206}$ In early July 1902, Settle reported that 257 prisoners had been deported to Bermuda and 75 to St Helena on penal servitude sentences, while there remained I 47 martial law prisoners in colonial gaols and $\mathrm{I} 53$ in the military prison at Grahamstown. CO 879/75/I, enc. I in No. 3 I 4 , p. 278.

207 PP I902 (Cd. I I63), enc. in No. 63, pp. I72-I73. These terms did not apply to those who had committed murder or crimes against the law of civilised warfare.

${ }^{208} \mathrm{CO}_{4} 8 / 562 / 26575$, f. I 83 . 
3,000 rebels had been convicted under the terms of the proclamation. ${ }^{209}$ The rebels were convicted by a legal procedure, albeit an expedited one. Preliminary proceedings - in which they signed their confessions - took place before a magistrate or officer appointed to accept surrenders. Once the Attorney General had accepted the surrender, the rebel returned to court, where he was handed a document stating that he had been tried and convicted of High Treason. ${ }^{210}$

\section{The Continuation of Martial Law}

As the war was drawing to an end, forty-two members of the legislative assembly petitioned Milner calling for a suspension of the Cape's constitution, to avoid recalling a parliament which would include members who had been tried for treason in the war, and to avoid the turbulence which would follow contested elections on the old franchise. Milner, who had himself on various occasions urged Chamberlain to modify or suspend the constitution, ${ }^{2 I I}$ gave strong support to the petition. In a letter to the Governor, published (without the Colonial Office's knowledge) in the Cape press, Milner suggested that, if the constitution were not suspended, 'Martial Law may have to be maintained for a much longer time. ${ }^{2 \mathrm{I} 2}$ Governor Hely-Hutchinson also told Chamberlain that, if the constitution were not suspended, martial law would have to remain in place for at least eight months. ${ }^{213}$ Chamberlain disliked this idea and wanted the political parties at the Cape to come to a concordat. Moreover, the proposal to suspend the constitution provoked strong opposition at the Cape. Among the opponents of suspension was Sir Henry de Villiers, who was horrified by Milner's letter. Fearing that the imperial parliament might act on it, he lobbied both the Liberal Imperialist Herbert Asquith and the

209 The return of 3 I August I90I in CO 879/77/3, No. 429, p. 407 gives the figure of 3,440. Shearing, 'The Cape Rebel', p. 258 states that 3, I 54 rebels were disfranchised under the Proclamation.

210 Shearing, 'The Cape Rebel', pp. 259-260.

${ }_{21 \mathrm{I}}$ See Headlam, The Milner Papers, vol. 2, pp. 55-61, 64-65, I82.

${ }^{212}$ Milner to Hely-Hutchinson, I9 May I902, 48/56I/239I6, f. I76. Chamberlain was 'Dismayed and seriously embarrassed' by the letter's publication: Chamberlain Papers, University of Birmingham, JC I/I $3 / 265$.

${ }^{213}$ CO $879 / 76 /$ I, No. 285 , p. 292 at p. 295. 
Canadian prime minister Wilfrid Laurier 'to assist in averting the calamity that is threatening us'. ${ }^{214}$ In these letters, he pointed out that Milner's comments were 'peculiarly unfortunate' in light of the decision in Marais 'that Martial Law can only be justified by the existence of actual hostilities'. ${ }^{215}$

However, with 200 martial law prisoners still in detention in the Cape, and thousands of rebels surrendering, Hely-Hutchinson was convinced that martial law had to remain in place until further security legislation and an indemnity act had been passed. At the same time, he realised the danger that applications would be made to the courts to release prisoners. ${ }^{216}$ Once it was clear that peace had been restored, they were likely to succeed. Given the political difficulty of securing the necessary legislation to validate martial law proceedings at the Cape, the Law Officers suggested imperial legislation; ${ }^{217}$ but Chamberlain perceived difficulties in the way of getting it through parliament. Both the minister and his officials therefore contemplated moving the detainees to the former republics, out of the reach of the Cape Supreme Court, but this suggestion was opposed on political grounds by the Attorney General. ${ }^{218}$ This left the authorities with a dilemma. 'Subject to appeal to the Privy Council, it is, in fact, at present, practically in the power of the Supreme Court to nullify the proclamations of Martial Law', Hely-Hutchinson wrote, 'even if the Government, which is responsible for the maintenance of order, does not consider it prudent as yet to rescind them. ${ }^{219}$

In the middle of June, ministers at the Cape began to press for a relaxation of martial law, including allowing those who had been removed to Port Alfred to return to their homes. ${ }^{220}$ Responding to their request, Settle said he was willing to relax unnecessary

${ }^{214}$ De Villiers to Laurier, 8 June I902, De Villiers Papers, National Library of South Africa (Cape Town), MSC 7 (Box 8).

${ }^{215}$ De Villiers to Asquith 8 June I902, De Villiers Papers, National Library of South Africa (Cape Town), MSC 7 (Box 8).

${ }_{12}^{216}$ CO $879 / 74 /$, No. I 57, p. I 83 ; CO $879 / 77 / 3$, No. 40 , p. I6.

217 Opinion dated 30 May I902, CO $885 /$ I 5 , No. I 5 I.

${ }_{218}$ Minutes, I7-I 8 June I902, $\mathrm{CO}_{48 / 561 / 24 I 2 I .}$

${ }_{219} \mathrm{CO} 879 / 77 / 3$, No. $4 \mathrm{I}$, p. I7 at p. I8.

220 The Cape Ministry addressed a minute to the Governor on I7 June calling for restrictions on movement to end and for the deportees to Port Alfred to be allowed to return: CO $879 / 77 / 3$, enc. I in No. 42, p. 21. The deportees were released on a gradual basis: $\mathrm{CO} 879 / 77 / 3$, enc. in No. 76 . 
restrictions, but did not feel that martial law could be abolished until a satisfactory system of civil policing had been established in every district. ${ }^{22 I}$ By early July, when it was clear that a state of war no longer existed which would satisfy the Marais test, Settle - who had received a three-and-a-half-page commentary on the case from de Villiers ${ }^{222}$ became more conscious of the risk of a clash with the Supreme Court. He now proposed to issue orders that no further action should be taken in the Cape Colony by the Administrators under martial law and that there should be no more martial law trials, while making it clear that he was still prepared to put the machinery of martial law into action at any time at the request of ministers. ${ }^{223}$ The proposal was that responsibility for martial law - which would remain in place until the necessary legislation was passed - would be transferred to the civilians. This was a proposal which ministers were happy to accept. $^{224}$

By early July, military-civilian negotiations had resulted in an arrangement whereby martial law remained in place, but under civilian control. If this was regarded as a more satisfactory political arrangement, it did not remove the risk that the courts might free those who had been detained or sentenced by martial law courts. It was evident that Chief Justice de Villiers's position on the question would be crucial, and officials soon came to the view that his behaviour might be influenced by his politics. De Villiers had continued to voice his passionate opposition to the suspension of the Cape constitution. In late June, he wrote to Chamberlain to reassure him that, if the Cape parliament met, it would pass the legislation necessary for the peace of the colony. He also promised to resign his judicial office and use all his influence in favour of reconciliation if these assurances proved false. ${ }^{225}$ Aware of these views, officials in London thought it politic for HelyHutchinson have a private word with the Chief Justice, to pass on Chamberlain's opinion that any conflict between the Supreme Court and the Executive over detentions 'might force the hand of H.M.G. and

${ }_{221} \mathrm{CO} 879 / 77 / 3$, enc. in No. 76, p. 42 at p. 43. ${ }^{222}$ Walker, Lord De Villiers, p. 4OI.

$223 \mathrm{CO} 879 / 77 / 3$, enc. I in No. I 57 , p. I I 5 .

$224 \mathrm{CO} 879 / 77 / 3$, enc. 2 in No. I 57, p. I I6. The arrangement (which Kitchener disapproved of) did not apply north of the Orange River, where Lyttleton was General Officer Commanding: see CO $879 / 77 / 3$, enc. 8 in No. I9I, p. I 5 I.

225 CO 879/74/I, No. I77, p. 206. 
thus prevent the settlement by "concordat" ${ }^{226}$ Having met de Villiers, Attorney General T. L. Graham expressed his confidence that, if a habeas corpus application were brought before the court, a rule nisi would be granted at a long enough date to allow an indemnity act to be passed. ${ }^{227}$ This removed Chamberlain's fear of a conflict between executive and judiciary, and it was soon followed by an official response turning down the petition to suspend the constitution. ${ }^{228}$

De Villiers did not, however, remain silent. Just at the moment when officials felt confident that the threat of a clash with the courts had been removed, he made his provocative comments in van Reenen's case. The immediate response of the Cape's Attorney-General was to recommend that any sentences passed since 3I May - the date of the peace - should be postponed indefinitely or considered for remission, to avoid the risk of a clash with the court. ${ }^{229}$ Settle accordingly issued an order that all people held in military custody for what were civil offences - including treason - should be handed over to the civil authorities, and that those held for breaches of martial law regulations should be dealt with summarily, but 'should suffer no penalty except a severe reprimand'. ${ }^{230}$ Officials in London agreed that the promulgation of sentences by martial law courts after the cessation of hostilities would not be defensible. At the same time, Bertram Cox was exasperated by the Chief Justice's remarks, which he felt were 'intended to have a political effect'. He pointed out that, whether or not sentences were postponed, it was now open to any martial law detainee to apply to the court for his release. In his view, the only way to avoid a clash with the Supreme Court - which would render the passing of an indemnity act politically impossible would be to end martial law. Ommanney, however, feared that this would unleash a flood of actions against 'all officers from

226 Note 20 June, CO 48/56I/23916, f. I76. Though some questioned the propriety of attempting to put pressure on de Villiers on a judicial matter, Chamberlain noted 'We shall be asking advice of not putting pressure upon the CJ.' Hely-Hutchinson was uncomfortable with this, fearing it would be perceived as an indirect approach to the Bond: CO 879/74/I, No I76, p. 20 I.

227 CO 879/74/I, No. I79, p $207 . \quad{ }^{228}$ PP I902 (Cd. I I62) LXIX. 425.

229 CO $879 / 77 / 3$, enc. 2 in No. I9I, p. I48; CO $879 / 74 /$ I, No. I90, p. 2 I I.

${ }^{230} \mathrm{CO} 879 / 77 / 3$, enc. 4 in No. I9I, p. I49. 
Kitchener down', and thought it better to wait for an indemnity act and trust de Villiers not to be 'too actively mischievous'. ${ }^{231}$

\section{The Martial Law Commission}

One of the main issues which had to be dealt with at the end of the war was what was to be done with those convicted by martial law courts. Although they had largely followed the procedure of military courts, under the Diceyan theory, they were simply committees putting into execution the discretionary powers assumed by the military and had nothing of 'law' about them. Any sentences would therefore expire at the end of the war, which would mean either that the convicted rebels would have to be freed, or that they would have to be retried in civilian courts. Chamberlain's solution, which he put to Milner, HelyHutchinson and McCallum on 26 June, was to appoint a commission to examine all unexpired sentences, and report on them before they were confirmed and validated by indemnity legislation both in the Cape and in Natal. ${ }^{232}$ A review of all outstanding sentences by a quasijudicial body would be able to legitimise them. A particular attraction of announcing such a commission early was that it might forestall the possibility of the Cape Supreme Court hearing habeas corpus cases. ${ }^{233}$

Ministers at the Cape supported this proposal, but argued for a wider commission, which would include a Supreme Court judge, and which would examine expired sentences as well as unexpired ones. ${ }^{234}$ This idea was strongly resisted by the Colonial Office and the Governor. In view of the recent acquittal of Pony De Wet by a bench of Cape judges sitting on the special treason court, Hely-Hutchinson recommended 'that the Commission should be appointed from home', and Chamberlain agreed that it had to be 'absolutely independent of local influence $\&$ feeling'. ${ }^{235}$ It was also feared that an examination of expired sentences would put the spotlight on controversial executions. They included not only high-profile Boer

\footnotetext{
${ }^{23 \mathrm{I}}$ Cox \& Ommanney notes, I 5 July I90I, $\mathrm{CO}_{4} 8 / 562 / 28534$, f. 588.

${ }^{232} \mathrm{CO} 879 / 74 / \mathrm{I}$, No. I69, p. I98.

233 See CO 879/74/I, p. 20I, No. I76; No. I77, p. 206.

${ }^{234} \mathrm{CO} 879 / 77 / 3$, No. II 5, p. 73; Sprigg to Chamberlain, 28 June I90I, Chamberlain Papers, JC I I/34/4.

${ }_{235}$ CO 879/74/I, No. I7I, pp. I98, I99; CO 879/74/I, No. I94, p. 2 I 2.
} 
commando leaders such as Gideon Scheepers, ${ }^{236}$ but also the case of H. J. van Heerden, a farmer from Zevenfontein, who had been shot by the military authorities, apparently without any trial, on 2 March I90I. ${ }^{237}$

It was settled by the middle of July that a royal commission would be appointed in London, consisting of Lord Alverstone CJ, Justice Bigham and Sir John Ardagh. Legislation would be passed at the Cape to validate all martial law sentences, but granting the Governor the power to amend any sentences in light of the recommendations of the commission. ${ }^{238}$ Once the indemnity act was passed, the martial law proclamation would be cancelled and the Peace Preservation Act I 3 of I 878 proclaimed throughout the Colony. ${ }^{239}$ The proposals were not uncontroversial. As the Bond newspaper Ons Land pointed out, in contrast to the position in I900, when Rose-Innes had reviewed the sentences before parliament confirmed them, on this occasion they were to be confirmed first, and revised later. ${ }^{240}$ At Westminster, the Irish Nationalist MP Swift Macneill criticised the appointment of English judges to a commission which dealt with 'a matter of purely domestic political concern' in a self-governing colony. He also challenged the impartiality of the members: both Alverstone (as Attorney General in Salisbury's government) and Bigham had sat on the South African Committee, appointed by the Colonial Office to investigate the Jameson Raid, and Ardagh had been director of military intelligence during the war. ${ }^{24 \mathrm{I}}$

Once in South Africa, the commissioners worked very quickly, beginning their sittings on 26 August and presenting their report on 28 October. They looked at 794 cases in all, of which 72I were from the Cape and 14 from Natal (the rest being from the former Republics). By Io September, the Commission was ready to recommend the immediate release of II 3 prisoners, who were freed by the Governor after the passage of the Cape's Indemnity Act a few days later. The final

${ }^{236}$ His martial law trial and execution was covered in The Times, 2I, 24, 25, 30 December I901, 20, 2I January 1902. See Judd and Surridge, The Boer War, pp. $235-236$.

237 For details, see Galbraith, 'British War Measures in Cape Colony', pp. 73-75.

${ }^{238}$ CO $879 / 77 / 3$, No. I09, p. $57 . \quad{ }^{239}$ CO $879 / 74 / 2$, No. II64, p. 377.

$24 \circ$ Ons Land, I2 August I902.

${ }^{24 I}$ Parl. Debs., 4th ser., vol. I I I, cols. I44I, I443 (28 July I902). 
report contained recommendations for the revision of sentences, in tabulated form: giving the original sentence, the recommendation of the commission, and the date of expiry. The recommendations of the commissioners were reported in the press. The Times noted that, in a 'large preponderance' of cases, the pattern was of a person originally sentenced to death for treason having his sentence confirmed by the military as penal servitude or life, and then reduced by the commission to two or three years. ${ }^{242}$ The Manchester Guardian reported that the tendency of the commission had been to cap sentences at five years' imprisonment, though the commissioners had left some severer sentences unaltered (such as the German Max Teinart's seven-year penal servitude sentence). In all, I 54 sentences were left unaltered. The commission also released men who had death sentences commuted to penal servitude for life in thirty-six cases. ${ }^{243}$

As a judicial body, the commissioners did not feel it was for them to recommend a general amnesty, which in any case they thought would be regarded 'as a sign of weakness, and as an adverse criticism on the action of Military Authorities'. In a memorandum drafted by Ardagh after their return to England, they praised the procedure used in the martial law courts which (in their view) had demonstrated a 'pervading spirit of impartial justice', and castigated the policy embodied in the I900 Indemnity and Special Tribunals Act as 'disastrous', considering that the effect of its leniency was to induce a large number to join the second rebellion. They also condemned the promise held out in Proclamation 100 of 1902 , and pointed out - 'in the strongest possible way' - that 'any legislative proceedings which minimise or belittle the offence of high treason are, and must be most disastrous to the well being of Governments.'244

Whereas the appointment of the commission was considered as essential to legitimise the martial law sentences of Cape rebels, the authorities in Natal wanted to be exempted from its operation. Governor McCallum told Chamberlain on 25 July that Natal's parliament had already confirmed all martial law sentences imposed before ro June by its Indemnity Act, and that the government wanted

${ }^{242}$ The Times, 2 December I902, p. 4.

${ }^{243}$ Manchester Guardian, 2 December I902, p. 7.

${ }^{244} \mathrm{PRO} 30 / 40 / \mathrm{I}$. A printed version of the memorandum is in $\mathrm{CO} 879 / 90 / \mathrm{I}$, No. 2 , pp. 2-4. 
to deal with any later cases through the prerogative of mercy. ${ }^{245} \mathrm{In}$ April, with the war coming to an end, Natal's Attorney General Henry Bale had expressed the view that the remaining 200 Natal rebels in the field 'should be left to be dealt with according to law'. ${ }^{246}$ However, in light of the promises made to the Boer leaders - that rebels outside Natal would not be returned to the colony to face trial - he and his ministers decided that the best policy would be to exercise the prerogative of mercy by allowing those who surrendered for trial to return to their homes with no greater punishment than disfranchisement, and by freeing anyone serving a sentence of up to two years. ${ }^{247}$ In response, Chamberlain indicated that, while he was happy for the Natal government to remit sentences before the commission began its work, he felt that the commission had to consider any cases where prisoners were still undergoing sentence at the time of the report. The commission's remit had been agreed with the Governor, and had been made public: it could not be altered now. ${ }^{248}$ Natal's response was to insist that the commission should not inquire into sentences validated by the Indemnity Act, but must deal only with court martial cases since the act. It was also insisted that any action taken on the report of the commissioners would be done by the Governor acting on the advice of the ministry. ${ }^{249}$ In the event, the commission considered only fourteen Natal cases, making no alteration of sentences in eleven cases.

\section{Pressures for a Wider Inquiry}

Many politicians at the Cape wanted to see a local commission appointed, which would have a wider remit than the Alverstone Commission. They had not forgotten Prime Minister Sprigg's promise of a general commission of inquiry into martial law in September 1900, provision for which had been made in the Indemnity and Special Tribunals Act. ${ }^{250}$ Although Chamberlain

245 CO $879 / 74 /$ I, No. 203, p. 217.

${ }_{246}$ PP I902 (Cd. 903), enc. in No. I2, p. I6; PP I902 (Cd. I096), No. 26, p. Io.

247 CO 879/74/I, No. I88, p. 2 I0; No. 234 and enc., pp. 23 I, 235.

248 CO $879 / 74 /$ I, No. 2 I I, p. 219; No. 22 I, p. 226.

249 CO 879/74/I, No. 226, p. 227, No. 233, p. 23 I.

${ }^{2} 5^{\circ} \mathrm{CO} 879 / 74 / \mathrm{I}$, No. 200, p. 2 I 6. Chamberlain opposed such a commission, seeing it as divisive: CO 879/74/I, No. 2I 5, p. 222. 
claimed that Sprigg had given him his 'personal pledge' that he would not appoint such a commission, ${ }^{25 I}$ the Prime Minister changed his position when parliament met, in effect 'simply offering a bribe to the Bond' (as Ommanney saw it) in return for passing the indemnity bill. ${ }^{252}$ In spite of stiff opposition from the Colonial Office and the Governor, Sprigg made it clear that he wanted a thorough investigation of martial law, and let London known that Justice Maasdorp had agreed to head it. ${ }^{253}$

In the meantime, loyalists in the Cape parliament thought they might head off the prospect of a wide-reaching local commission by extending the Alverstone Commission's remit to look into expired sentences. ${ }^{254}$ However, Alverstone himself was opposed to this policy, ${ }^{255}$ since he thought that the imperial government should keep control of the inquiry, and that 'under no circumstances should the conduct of the military officers or their good faith be impugned. ${ }^{256}$ Nor did Chamberlain have any appetite for any wider inquiry. 'I have no doubt many irregular things were done', he noted, 'but even so what is the good of raking them up unless full compensation is to be accorded to any aggrieved person?' Lambert agreed: 'I fear that a great deal of martial law [administration] will not bear investigation.' Faced with the choice of an extended Alverstone commission (the loyalist proposal) and a local investigation (Sprigg's proposal, backed by the Bond), Chamberlain preferred the latter, since London could 'wash our hands of the whole business' and let the Cape government fund any compensation claims.

${ }^{25 \mathrm{I}}$ Minute dated 20 August $\mathrm{I} 902$ in $\mathrm{CO}_{4}$ 8/564/3470I; see also CO 879/74/I, No. 246, p. 24I; No. 2I6, p. 222.

252 Minute of I 8 August I902, in $\mathrm{CO}_{4} 8 / 564 / 34328$, f. I6.

${ }_{253} \mathrm{CO} 879 / 74 /$ I, No. 253 , p. 243.

254 Hely-Hutchinson estimated at the end of August that there were 390 expired court martial sentences (and 7,000 expired sentences of cases before Deputy Administrators of Martial Law), alongside 700 or so unexpired martial law sentences: CO 879/74/I, No. 266, p. 250.

${ }^{255} \mathrm{CO} 879 / 74 /$ I, No. 274 , p. 256 . After the act had passed, the Cape assembly formally requested that the remit of Alverstone's commission be extended to take into account expired sentences, as well as unexpired sentences. However, the request was refused. While the Colonial Office could plausibly claim that the two English judges were required at home, it was clear that Alverstone himself regarded the request as 'absolutely out of the question'. Note by Lambert, 25 September I902, CO 48 / 565/399II, f. 329; CO 879/74/2, No. I399, p. 46I.

${ }_{256}$ Alverstone to Chamberlain, Io September I902, CO 48/565/37743, f. Iо. 
In all these tortuous proceedings, London's main concern was to get an indemnity bill passed, and it was prepared 'to play Sprigg a little till this is done'. ${ }^{257}$ At the same time, imperial officials were frightened that the Cape parliament would look closely at cases like van Heerden's before passing the indemnity act. As Hely-Hutchinson told Chamberlain, there were members of the assembly who knew the facts of the case, and although (in his view) 'Van Heerden probably deserved to be shot the proceedings of the Court Martial will not hold water'. More worryingly, the real facts did not justify the entry in the Blue Book of sentences which the Alverstone Commission was set to revise, which threatened to cast a shadow over its proceedings. ${ }^{258}$ In the end, a promise by Sprigg to appoint a local commission of the sort anticipated in the 1900 Act - which leading Bond members saw as giving them a chance to expose the evils of military law - secured the passage of the bill without incident in the assembly. ${ }^{259}$

Sprigg's promise in turn generated concern among officials in London over how to deal with the recommendations of any local commission which might be appointed. One important question was whether the Governor would be bound to follow the advice of his ministers, if they instructed him to pardon those sentenced by martial law courts. ${ }^{260}$ In October, Bertram Cox referred this question to the Law Officers, asking them whether the Governor could refuse on the grounds that imperial interests were at stake. The advice confirmed that the Governor did have the power to reject an amnesty, though officials were sensitive to the political risks of seeking to ignore the views of a ministry. ${ }^{26 \mathrm{I}}$ Officials also pondered the constitutionality of asking the Governor to refuse to appoint any local commission, and considered how its work might be frustrated, for instance by removing all relevant documents in the possession of the military out of the colony. ${ }^{262}$

257 Note, 26 August I902, CO 48/564/35227, f. I94; CO 879/74/I, No. 273, p. 249.

${ }^{258} \mathrm{CO} 879 / 74 / 2$, No. I I 72, p. 380 , referring to the entry in PP I902 (Cd. 98 I), p. I 25 , which reported van Heerden's sentence by a court martial.

259 CO 879/74/I, No. 287, p. 272.

${ }^{260}$ Graham note, I I September I902, CO 48/565/37710, f. 3 .

${ }^{26 I}$ Law Officers' Opinion I 6 October I 902, CO 48/568/43073, f. 54

262 Chamberlain to Brodrick, 2 September I902, CO 48/564/36016, f. 366 ; HelyHutchinson to Chamberlain, Io September I902, CO 48/565/37743, f. I6; CO 879/74/I, No. 306, p. 298; No. 293, p. 278 ; No. 295, p. 279. 
The problem remained hypothetical as long as no local commission was appointed. However, in the meantime, the Cape Legislative Council began to investigate of particular cases. In August, the petition of M. J. Pretorius, a member of the assembly, was referred to a select committee. He had been detained under martial law at Middelburg - where he had been ordered to attend the execution in July I90I of F. A. Marais - and was later sent to Port Alfred as an undesirable. He had been told by the Martial Law Board that the reason for his expulsion was that he had not handed over horses which had been commandeered (a finding he disputed); but had not been allowed to return home until 29 July I902. When the committee proceeded to deal with his complaint, its members were told by General Settle that the officers they wished to interview had left the country, while the Martial Law Board also refused to hand over its documents. ${ }^{263}$ The committee reported that it could find no evidence that he had used any seditious language, but that he had been subjected to indignities and restrictions on his liberty. It also concluded that the Martial Law Board had failed in its duty of protecting British subjects from 'injustice and wanton oppression'. ${ }^{264}$

The Board's chairman, Lewis L. Michell, lost little time in protesting about this finding, explaining to the Governor that the real charge against Pretorius had been that he was using his influence as a member of the legislature 'in the wrong direction'. He also expressed his view that his deportation to the coast had a tranquillising effect on the district of Middelburg. ${ }^{265}$ HelyHutchinson was also irked by the report, since he felt it was in the interest of those wanting a general inquiry to discredit the Martial Law Board. He also considered that in its criticism of the Board, the report, drafted by Sir Henry de Villiers, had violated a principle of justice, namely that no one should be condemned unheard. In London, Bertram Cox dismissed as worthless the 'proceedings of a Bond committee taking evidence ex parte', noting that 'Pretorius seems to have been a typical Dutch Africander. He sends his sons to fight $\&$ sits $\&$ whines at home.

\footnotetext{
263 CO $879 / 78 / 4$, No. 28 (with encs.), p. 57.

264 CO $879 / 78 / 4$, enc. I in No. I I 8 , p. I90 at p. I92.

265 CO $879 / 78 / 4$, enc. 7 in No. I I 8 , p. 195.
} 
Chief Justice De Villiers I believe did the same. ${ }^{266}$ Other cases were also investigated by select committee, without the benefit of military co-operation, revealing information which officials in London had to admit was 'certainly not favourable to military justice'. ${ }^{267}$ Try as they might to prevent scrutiny of wartime cases, political pressure at the Cape ensured that material embarrassing to the imperial authorities came into the public domain.

The appointment of a wide-reaching local commission of inquiry was avoided, however. By the time the session of the Cape parliament ended, in the middle of November, no local commission had yet been appointed, though the promise of one was still being held out. ${ }^{268}$ When parliament reassembled in 1903 , Bond members were keen to return to the issue, but by then, Sprigg had again changed his mind, now taking the view that his promise from I 900 to appoint a commission had been superseded by events. Consequently, when in August the lawyer Henry Burton called for a Supreme Court judge to be appointed to report on the sentences imposed under martial law in any cases where fines were imposed, and to constitute a court of appeal from any decisions of the War Losses Compensation Commission, Sprigg warned that, if the motion were passed, he would resign. ${ }^{269}$ Having taken this position, it soon became clear that the Bond would not agree to the passage of Sprigg's Supply Bill, since they were pledged to an amnesty and an inquiry into martial law. The Prime Minister consequently advised the Governor to dissolve the assembly and issue Treasury warrants, as had been done in the war, and trusting to an indemnity by a subsequent parliament. In brief, faced with Sprigg's threat to resign, and having to call on a ministry whose supporters were 'tainted with treason and rebellion'. Hely-Hutchinson agreed to the dissolution. ${ }^{270}$ When elections to the assembly were next held in 1904, a Progressive majority was returned, and the question of a commission to investigate martial law fell off the agenda.

${ }^{266}$ Hely-Hutchinson to Chamberlain I4 October I902, and notes of officials: CO 48/ $565 / 45407$, f. 692; see also Cox's note, 20 January I903, in CO 48/568/5 I879, f. 689 .

267 Note by Lambert on the case of J. H. Schoeman, 23 October I902, CO 48/565/ 45202 .

268 Manchester Guardian, 8 December I902, p. Iо.

269 Davenport, The Afrikaner Bond, p. $246 . \quad{ }_{270}$ CO 879/90/I, No. 50A, p. 49. 


\section{Conclusion}

Questions about the nature of martial law, and how far it was subject to the rule of law, returned to the public agenda during the Anglo-Boer war in a way that had not been the case since the Morant Bay rebellion. This was not only because of the unprecedented scale on which martial law powers were exercised, or the numbers detained or imprisoned after martial law trials. It was also because, in this war, those who were being detained and imprisoned in this way were white subjects, with the full citizenship rights of British subjects, living in colonies with representative governments.

As R. W. Kostal has shown, the Jamaica controversy had revealed two rival conceptions of martial law, one of which (espoused by Governor Eyre's critics) saw all actions taken in emergencies as being subject to common law review, and the other of which (championed by his defenders) defended a 'jurisprudence of power' which regarded martial law as a legitimate means of defending imperial interests. ${ }^{27 \mathrm{I}}$ As has been seen in earlier chapters, as the British extended their rule in other parts of Africa, a vision endorsing the 'jurisprudence of power' was often in the ascendancy, with arbitrary actions legitimated by formal legislative fiat, issued by legislators whose authority derived ultimately from the imperial parliament in Westminster, in whose name these new subject peoples were conquered. But such an approach was not so easy to adopt where the people whose rights were violated were white subjects, as opposed to subjected black Africans. In South Africa, it became evident that the rule of law was as much a matter of culture, or state of mind, as it was of doctrine or jurisdiction.

This war raised hitherto unanswered questions about the rule of law, which often needed to be settled by negotiation by parties who took different views of it. One question concerned the status of martial law. If the military inclined to Finlason's view that the crown had a prerogative power to take all actions it considered necessary in times of emergency, and the civilians inclined to Dicey's view that all military actions were subject to judicial review, in practice both came to accept that a proclamation of martial law initiated a particular kind

${ }^{271}$ Kostal, A Jurisprudence of Power, p. 465. 
of legal regime, whose parameters needed to be negotiated and defined. How far a culture of the rule of law could be maintained in this world depended on how influential political voices in its favour, backed by the threat not to indemnify the military, could be, in face of military demands to win the war by all means. It is notable that, in this context, the colonial courts - under Chief Justice de Villiers - became increasingly assertive in seeking to limit the military's power to detain without trial. It is equally notable that the highest imperial court, the Privy Council, in the landmark decision of Marais confirmed the power of the military to take action unfettered by the court during the emergency. The approach of Halsbury - who had been Eyre's lawyer - was to treat the military's powers durante bello as equivalent to those conferred by a continental state of siege: a formal power conferred by the state of war. His views differed entirely from the Diceyan views of de Villiers, who found himself outvoted on the same court. Their views of the rule of law might have reflected their wider political sentiments: whereas the judge from the Cape felt a deep sympathy towards the detained fellow Dutch-speakers, the conservative Lord Chancellor's views may have been more in line with those of men like Milner, for whom the Cape Dutch were at best potentially disloyal, at worst the enemy in a struggle to decide which of the two 'white races' would prevail. ${ }^{272}$ As Halsbury had shown in 1890 in Cox v. Hakes, he was willing to give a liberal interpretation of the reach of the writ of habeas corpus when the rights of high church English clergymen were at stake; but he was not prepared to take such a liberal view when dealing with imperial enemies. ${ }^{273}$

Halsbury's view of martial law shielded the military only until the war ended, when an indemnity act would be needed. When it came to

${ }^{272}$ This may be said to characterise the views of the Secretary of State, Joseph Chamberlain, and the Governor of the Cape and High Commissioner Sir Alfred Milner. Milner complained to Chamberlain on I 4 November 1900 of the 'superstition' held by many at home 'that you can govern a country, in which the majority of citizens are your enemies, by a system of autonomy more complete than any separatist ever proposed even for Ireland'. Bodleian Library, MS Milner dep. I70, f. I 57. See also Le May, British Supremacy in South Africa, pp. 3 I-34.

273 Cox v. Hakes (I 890) I 5 App. Cas. 506, where his judgment began at 5I4, 'For a period extending as far back as our legal history, the writ of habeas corpus has been regarded as one of the most important safeguards of the liberty of the subject.' 
passing indemnity legislation, it became evident, particularly in the majority Dutch-speaking Cape, that the legislature would not be content simply with passing a formal statute to whitewash the military. Martial law sentences were confirmed, but only after a process of sentence revision, designed to assure legislators that the sentences were not unjust. In this context - where former white rebels needed to be re-integrated into a post-war political order - the same rule-of-law concerns which had animated de Villiers's judgment were once more in evidence. As shall now be seen, such concerns were far less in the ascendant when martial law returned to South Africa in I906, with the view of suppressing a Zulu rebellion. 